Biosystems Engineering, Volume 84, Issue 4, April 2003, Pages 513-531.

\title{
Real-time Measures of Canopy Size as a Basis for Spatially Varying Nitrogen Applications to Winter Wheat sown at Different Seed Rates
}

\author{
G. A. Wood ${ }^{1}$; J. P. Welsh ${ }^{1}$; R. J. Godwin ${ }^{1}$; .J. C. Taylor ${ }^{1}$; R. Earl' ${ }^{1}$; S. M. Knight ${ }^{2}$ \\ ${ }^{1}$ Cranfield University at Silsoe, Silsoe, Bedfordshire MK45 4DT, UK; e-mail of corresponding author: \\ g.a.wood@cranfield.ac.uk \\ ${ }^{2}$ Arable Research Centres, Shuttleworth Centre, Old Warden Park, Biggleswade, Bedfordshire SG18 9EA, UK
}




\section{Abstract.}

Experiments at two sites growing winter wheat show that in order to manage a wheat canopy more effectively, the use of specific remote sensing techniques both to monitor crop canopy expansion, and to determine variable nitrogen applications at key timings is required. Variations in seed rate were used to achieve a range of initial crop structures, and treatments were compared to standard farm practice. In the first year, the effect of varying seed rate (250, 350 and 450 seeds $\left.\mathrm{m}^{-2}\right)$ on crop structure, yield components and grain yield, was compared to the effects of underlying spatial variation. Plant populations increased up to the highest rate, but shoot and ear populations peaked at 350 seeds $\mathrm{m}^{-2}$. Compensation through an increased number of grains per ear and thousand grain weight resulted in the highest yield and gross margin at the lowest seed rate. In later experiments, the range of seed rates was extended to include 150 seeds $\mathrm{m}^{-2}$, each sown in $24 \mathrm{~m}$ wide strips split into $12 \mathrm{~m}$ wide halves.

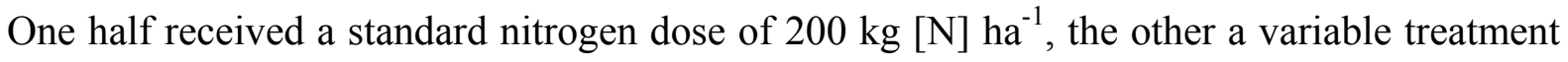
based on near 'real-time' maps of crop growth. Both were split into three applications, targeted at mid-late tillering (early March), growth stages GS30-31 (mid April) and GS33 (mid May). At each timing, calibrated aerial digital photography was used to assess crop growth in terms of shoot population at tillering, and canopy green area index at GS30-31 and GS33. These were compared to current agronomic guidelines. Application rates were then varied below or above the planned amount where growth was above or below target respectively. In the first field, total nitrogen doses in the variable treatments ranged from 188$243 \mathrm{~kg}[\mathrm{~N}] \mathrm{ha}^{-1}$, which gave higher yields than the standards at all seed rates in the range 0.36-0.78 $\mathrm{t} \mathrm{ha}^{-1}$ and gross margins of $£ 17-60 \mathrm{ha}^{-1}$. In the second field, variable treatments ranged from $135-197 \mathrm{~kg}[\mathrm{~N}] \mathrm{ha}^{-1}$ that resulted in lower yields of -0.32 to $+0.30 \mathrm{t} \mathrm{ha}^{-1}$. However, in three out of the four seed rates, variable treatments produced higher gross margins than the standard, which ranged from $£ 2$ to $£ 20 \mathrm{ha}^{-1}$. In both fields, the greatest 
benefits were obtained where the total amount of applied nitrogen was similar to the standard, but was applied variably rather than uniformly along the strips. Simple nitrogen balance calculations have shown that variable application of nitrogen can have an overall effect on reducing the nitrogen surplus by one third.

\section{Introduction}

A number of studies (Carr et al., 1991; Mulla et al., 1992) have examined the potential for applying variable rates of fertiliser within fields to improve economic performance and minimise environmental impact. In addition, a range of approaches for determining management strategies for applying variable fertiliser have been examined including topography (Nolan et al., 1995); soil sampling with grids (Vetsch et al., 1995); yield maps (Kitchen et al., 1995). Other work included the use of remotely sensed canopy reflectance data to monitor the effects of applying nitrogen (Blackmer et al., 1994), and to detect nitrogen deficiency (Blackmer et al., 1996). However, no work has been published that develops the use of optical remote sensing techniques to determine nitrogen requirements or to produce nitrogen application maps. A similar technique to optical remote sensing, although fundamentally different in terms of implementation - based on principles of light transmission rather than reflection - is the use of chlorophyll meters for estimating nitrogen requirements (Chapman \& Barreto, 1997). The labour intensive nature of this approach would prohibit its use for commercial precision farming. Unlike remote reflectance measurements, the chlorophyll meter estimates $\mathrm{N}$ concentration and not the total $\mathrm{N}$ content.

A standard recommendation for UK wheat growers has been to sow sufficient seeds to produce 300 plants $\mathrm{m}^{-2}$ by spring based on an average post-winter establishment of $70 \%$ (HGCA, 1998). Whaley et al. (2000) showed that plant populations in wheat can be lowered to 120 plants $\mathrm{m}^{-2}$ and still achieve the same yield, through compensations in increased green 
area per shoot, extending tillering phase, greater radiation use efficiency and better partitioning of resources within the plant. The effect of sowing date on optimum plant populations was reviewed by Spink et al. (2000) who showed that populations could be as low as 62 plants $\mathrm{m}^{-2}$ if sown early in September.

This paper reports on the findings of a three year experiment starting in 1996, at four commercial sites with soils representing $30 \%$ of land used in arable production in England and Wales. Initially, the reasons for the underlying field variation were established prior to managing the crop in a spatially variable manner (Earl et al., 2003 and Taylor et al., 2003).

During the period 1997-2000 a series of spatially variable management strategies were investigated and reported by Welsh et al. (2003a and 2003b). The conclusions from these initial studies showed that crop response to nitrogen could vary spatially within fields but was highly dependent on seasonal variations such as rainfall and available water. Variations in crop structure were monitored in near real-time by calibrating airborne digital photography (ADP) to provide accurate maps of shoot population. Applying more nitrogen $(\mathrm{N})$ on areas of low initial shoot population, and holding back $\mathrm{N}$ on areas of high shoot population produced extra yield benefits of up to $0.5 \mathrm{t} \mathrm{ha}^{-1}$ in comparison with standard farm practice. This socalled 'shoot density approach' offered considerable potential as a basis for varying $\mathrm{N}$ rates as it takes account of current conditions in the growing crop However, in some years the strategy performed better than in others. This was because 'high' and 'low' shoot population were terms used to express target populations as relative to the field average, which varied from one season to the next; the strategy needed to be applied within a more robust agronomic framework that used 'absolute' rather than 'relative' shoot target values.

Based on canopy management research by Stokes et al. (1998), the Wheat Growth Guide was published by the HGCA (1998) which provides a set of benchmark targets against which a wheat crop can be monitored to inform better management towards an optimum canopy 
green area index (GAI). The work reported by Wood et al. (2003) led to the delivery of accurate maps of shoot density and GAI from calibrated ADP images to provide a timely opportunity for the application of the work by Stokes et al. (1998). An equivalent guide for barley is currently unavailable, although, after a limited three years of data, a better understanding of shoot population targets in barley has been reached (Welsh et al., 2003a).

The objective of the work presented in this paper was to develop and evaluate the management of canopy expansion for achieving an economically optimum 'canopy size' for yield. Variations in seed rate were used to produce a range of crop structures. Measures of canopy size would be used to plan applications strategies, to determine application rates and to monitor the rate of canopy expansion. Remote sensing techniques, developed by Wood et al. (2003), were used to provide the canopy measurements.

\section{Materials and methods}

\subsection{Sites and soils}

The experiments took place in two commercial field sites in Bedfordshire, UK with medium to heavy clay loams over clay. Onion Field, Houghton Conquest in 1997-98, 199899 and 1999-2000 (O/S TL 056 422), predominantly comprises Evesham series, a seasonally waterlogged, swelling clay soil with zones of Oxpasture, a clay loam over clay prone to slight seasonal waterlogging; further details of this site can be found in Earl et al. (2003). The other field, Far Highlands, Shuttleworth in 1999-00 (Ordnance Survey reference: TL 135 456) comprises Wickham series with small areas of Evesham series on the hill crests in the south and west of the field. Wickham soils are medium to heavy loamy drift over Oxford clay. Both fields had been cropped with wheat for several years previously and would remain so for the duration of the project. 


\subsection{Experimental design: variable establishment by seed rate}

This experiment took place in Onion Field in the 1997-98 cropping season and is referred to as ON98. The objective of the experiment was to introduce differing plant populations through varying seed rate on a field scale, and to relate initial establishment to subsequent variation in crop structure and yield components. The variation in compensation would be analysed to determine the potential of varying seed rate as a way of beneficially managing initial crop structure. Observations were made against a background of spatially variable soil conditions with uniform, split applications of $\mathrm{N}$ fertiliser. This was complementary to a set of field experiments where $\mathrm{N}$ rate was varied in order to alter crop structure using a uniform seed rate (Welsh et al., 2003a; Welsh et al., 2003b).

The experiment was set out in a series of strips sown with 250,350 and 450 seeds $\mathrm{m}^{-2}$ of winter wheat (cv. Riband) running orthogonal to the main areas of variation within each field as shown in Fig. 1, all subsequently managed conventionally.

\subsection{Experimental design: seed rate and $N$ interactions}

The objective of this experiment was to determine the benefits of controlling crop structure by also varying the rate of fertiliser $\mathrm{N}$ to control the growth of the crop towards an economically optimum canopy size. In addition to expected inherent field variation in establishment, different seed rates were again drilled in uniform strips to provide a deliberate variation in initial plant establishment. The aim was to achieve an optimum GAI by the beginning of anthesis (growth stage GS61).

Experiments were run over two years: in Onion Field in 1998-99, referred to as ON99, which was repeated in 1999-2000 (ON00) and shown in Fig. 2. In 1999-2000, the experiment was duplicated in Far Highlands and referred to as FH00 and is shown in Fig. 3. Each field 
layout comprised a series of $12 \mathrm{~m}$-wide, field-length strips of four different seed rates of 150 , 250,350 and 450 seeds $\mathrm{m}^{-2}$.

The standard strips represented 'standard farm practice' and received three split-timing, uniform applications of $\mathrm{N}$ at a rate of $200 \mathrm{~kg}[\mathrm{~N}] \mathrm{ha}^{-1}$, targeted at mid-to-late tillering (early march), then at GS31 (April) and again at GS33 (May). The exception to this was in FH00 when the second application took place at GS30, and not GS31. The variable N applications were also split over the same three timings. Application rates were determined by crop canopy size measured by remote sensing techniques following methodology developed in earlier experiments reported in Welsh, et al. (2003b), but developed further along the lines of Canopy Management (Stokes et al., 1998). All other inputs, such as P, K, herbicides and fungicides, were applied uniformly by the host farm managers independently of the main experimental work.

\subsection{Overview of nitrogen strategy}

At the timing of each $\mathrm{N}$ application, the size of the wheat canopy was measured and mapped using airborne digital photographs (ADP) (Wood et al., 2003) to derive calibrated maps of shoot population and GAI. The total amount of $\mathrm{N}$ fertiliser to be applied to areas ontarget was determined using rules proposed by Stokes et al. (1998). A worked example is provided in parentheses to illustrate each stage.

(1) Set target GAI (e.g. 6.5).

(2) Determine the GAI of the current crop (e.g. 0.5).

(3) Calculate the additional units of GAI required to achieve the target GAI of 6.5 (e.g. $6.5-0.5=6.0)$. 
(4) Assume the crop has a canopy nitrogen requirement (CNR) of $30 \mathrm{~kg}[\mathrm{~N}] \mathrm{ha}^{-1}$ to produce each unit of GAI.

(5) Determine the total $\mathrm{N}$ requirement of the crop to reach the target GAI (e.g. $6.0 \mathrm{x}$ $\left.30 \mathrm{~kg}[\mathrm{~N}] \mathrm{ha}^{-1}=180 \mathrm{~kg}[\mathrm{~N}] \mathrm{ha}^{-1}\right)$.

(6) Determine the soil mineral $\mathrm{N}$ supply (e.g. $75 \mathrm{~kg}[\mathrm{~N}] \mathrm{ha}^{-1}$ ) and deduct from $\mathrm{N}$ requirement (e.g. $180-75=105 \mathrm{~kg}[\mathrm{~N}] \mathrm{ha}^{-1}$ ).

(7) Now calculate the total fertiliser $\mathrm{N}$ requirement of the crop, assuming that not all the applied $\mathrm{N}$ will be recovered (e.g. $40 \%$ to $80 \%$ ).

(8) Assuming an average recovery rate of applied $\mathrm{N}($ e.g. $60 \%)$ calculate fertiliser rate (e.g. if $60 \%$ of $\mathrm{N}$ is recovered, $175 \mathrm{~kg}[\mathrm{~N}] \mathrm{ha}^{-1}$ must be applied to supply 105 $\mathrm{kg}[\mathrm{N}] \mathrm{ha}^{-1}$ to the crop).

(9) Apply 40-50 kg [N] ha ${ }^{-1}$ at the first $\mathrm{N}$ timing, and apply the remainder (e.g. 125$\left.135 \mathrm{~kg}[\mathrm{~N}] \mathrm{ha}^{-1}\right)$ at the main dose.

(10) Apply an extra $40 \mathrm{~kg}[\mathrm{~N}] \mathrm{ha}^{-1}$ at the third timing for canopy survival.

This procedure was developed for uniform applications of $\mathrm{N}$ and was applied to areas of the field at the target canopy size. These application were varied when the crop canopy size was above or below target and, in this way, the strategy deviated from the work of Stokes et al. 1998). Areas above-target received a reduced (or zero) $\mathrm{N}$ dose, and areas below-target received an increased amount of N. Initially, canopy size was measured by its shoot population density and then by GAI for the second and third applications. The specific timings are now discussed. 


\subsection{First nitrogen application}

The aim is to achieve a target GAI by GS61, which is a product of the final shoot density and the green area per shoot (GAPS). Sylvester-Bradley et al. (2000) showed that fewer shoots are required to achieve the same GAI at GS61 in crops with lower initial plant populations because the GAPS is higher than crops with lower plant populations. The estimated green area per shoot at GS61 was determined from Eqn 1 (derived from SylvesterBradley et al., 2000) for a given plant population (P).

$$
\mathrm{G}=154-0.2 P+0.0002 P^{2}
$$

The ultimate number of shoots required to produce the optimum GAI at GS61 was determined by dividing the target GAI by the GAPS. By factoring-in the expected shoot survival (c.50\%), the desired shoot population at GS31 was estimated. The first $\mathrm{N}$ application was made before tillering was complete and so an estimated percentage-completion of tillering was used to adjust the shoot population target for the $\mathrm{N}$ application date.

\subsection{Main dose}

For the second $\mathrm{N}$ application at GS31, canopy expansion was managed according to variations in the GAI mapped using ADP techniques. The GAI maps were used to compare the current growth pattern to the target benchmark as set out in the Wheat Growth Guide (HGCA, 1998). The main dose was adjusted according to the matrix in Table 1, which takes into account the current canopy-size status and the previous treatment dose rates.

\subsection{Final dose}

An extra $40 \mathrm{~kg}[\mathrm{~N}] \mathrm{ha}^{-1}$ for canopy survival was applied to areas of the field on-target in line with canopy management at GS33 (Stokes et al., 1998). Measures of the crop GAI were 
again compared to recommended targets as set out in the Wheat Growth Guide, and classified as above-target, below-target or on-target accordingly. The third and final 'survival' dose was then adjusted as follows in order to receive the following $\mathrm{N}$ treatment:

(1) if GAI = 5.5 - 7.0 (on-target), a canopy survival dose $\left(40 \mathrm{~kg}[\mathrm{~N}] \mathrm{ha}^{-1}\right)$ was applied;

(2) if GAI > 7.0, no canopy survival dose was applied; and

(3) if GAI $<5.5$, extra $\mathrm{N}$ was applied.

\subsection{Field measurements}

Sampling points were established in four transects in ON98, ON99, and ON00 traversing the experimental strips $c .100 \mathrm{~m}$ apart as shown in Fig. 2 and Fig. 3. Plant population was measured at each of the sampling points (three quadrats per sampling point) along the transects in November and February. Shoot population (two quadrats per point) and biomass (one quadrat) were also assessed at GS30 at each of the sampling points. Destructive samples for biomass assessments were made at harvest which also provided a sample to measure crop height and the components of yield: ear number, grain number per ear, and thousand grain weight (TGW). Leaf concentrations of $\mathrm{N}, \mathrm{K}, \mathrm{P}, \mathrm{Mg}, \mathrm{Mn}, \mathrm{Cu}, \mathrm{Zn}$, and $\mathrm{S}$ were determined in April by plant tissue analyses. Soil mineral $\mathrm{N}$ was assessed in the autumn using a ' $\mathrm{W}$ ' sampling pattern to provide baseline data for the field. In ON99 and ON00 the north-eastern and south-western parts of the field were assessed separately. In FH00, the east half of the field was assessed separately to the west. A 'W' sampling pattern was used for each independent assessment. Other soil elements (P, K, Ca, Mg, S, Mn, B, Cu, Mo, Fe and Zn), $\mathrm{pH}$ and organic matter were assessed in both autumn and spring (April). A ' $\mathrm{W}$ ' sampling strategy was used in the autumn, whilst soil samples from only selected sampling positions were taken from 0-0.3 $\mathrm{m}$ depth in the spring. 
In ON99, additional destructive samples, taken $6 \mathrm{~m}$ away from the transect sample points in the direction of field operations, were processed in the laboratory for biomass, shoot population, green area per shoot, GAI, and $\mathrm{N}$ concentration. These provided the basis for monitoring the effect of managing crop structure with variable $\mathrm{N}$ through the season. The same measures were made in FH00, however, the samples were not aligned in transects. Samples were targeted using a remotely sensed image of the crop acquired at GS13. Unlike ON98-ON00, routine soil and crop samples on transects were not made in FH00, which was included as an additional experimental site intended to receive only minimal monitoring in line with what was ultimately to be conventional field practice.

The ultimate crop response to the different seed rates was assessed in terms of grain yield and recorded by harvesting the length of each strip using a Massey Ferguson combine harvester equipped with a yield mapping system. Moore (1998) measured the performance of this yield monitor and showed that it underestimated the average yield of a field by approximately $20 \mathrm{~kg} \mathrm{ha}^{-1}$ with the standard error of individual observations equivalent to 155 $\mathrm{kg} \mathrm{ha}^{-1}$.

\subsection{Remote sensing}

Remotely sensed images were acquired during crop establishment and prior to each $\mathrm{N}$ fertiliser application. The images served to monitor variation through the season in all fields and to direct inputs of variably applied $\mathrm{N}$ in ON99, ON00 and FH00. The remotely sensed data was collected using an aerial digital photographic (ADP) system, which comprised two Kodak DCS420 digital cameras (Graham, 1994) mounted in a light aircraft to provide vertical images in two wavebands. Optical band-pass filters were selected in both the red (R) electromagnetic wavelengths, $640 \mathrm{~nm}$ with a half-maximum response of $10.4 \mathrm{~nm}$, and the near-infrared (NIR) wavelengths, $840 \mathrm{~nm}$, with a half-maximum response of $11.7 \mathrm{~nm}$, fitted 
in front $18 \mathrm{~mm}$ lenses of the cameras. The charge coupled device (CCD) camera array produced images made up of 1012 by 1524,8 -bit pixels, with a nominal field-of-view of 500 by $750 \mathrm{~m}$. Images were acquired at an altitude of $1000 \mathrm{~m}$, giving a nominal ground resolution of $0.5 \mathrm{~m}$. The cameras were exposed for $1 / 125$ second, at $\mathrm{f3.5}$, and set to an ISO400equivalent film sensitivity. Fired simultaneously using a remote trigger, the digital images were automatically stored on computer disk for processing.

The ADP system recorded the red and near-infrared image bands simultaneously on the two separate camera hard disks. The two wavebands were combined by digitally overlaying one on the other in ERDAS Imagine (v4.0, ERDAS Inc.) to a root mean square (RMS) error of less than $1 \mathrm{~m}$. The red and near-infrared bands were processed into a normaliseddifference vegetation index (NDVI) image using Eqn (2):

$$
\mathrm{I}_{N D V}=\left(\lambda_{D N 840}-\lambda_{D N 640}\right) /\left(\lambda_{D N 840}+\lambda_{D N 640}\right)
$$

where: $\mathrm{I}_{N D V}$ is the normalised difference vegetation index; and $\lambda_{D N 640}$ and $\lambda_{D N 840}$ denote the use of digital numbers measured at the red and near infrared spectral wavebands.

The NDVI was calculated using raw digital number (DN) values, recorded by the sensor, rather than transforming the DNs to equivalent radiance values or reflectance (Goward et al., 1991). Both methods of calculation lead to different NDVI values. Full radiometric calibration is required for inter-comparisons of NDVI from different sensors and different solar zenith angles. This work required only the relative differences of the NDVI across single localised images, individually calibrated with ground observations, so the use of raw DN values was appropriate.

A methodology for accurately mapping within-field variation of shoot population and GAI of wheat, by linear correlation with the NDVI, was used in these experiments which was 
initially developed by Taylor et al. (1997) and developed further by Wood et al. (1998 and 2003). The NDVI images were calibrated to provide maps of continuous estimates of shoot population across each field prior to each $\mathrm{N}$ application date.

\section{Results}

\subsection{Onion Field 1998}

Table 2 shows the three seed rates resulting in a proportional response of spring plant populations in the range $162-243$ plants $\mathrm{m}^{-2}$. On average, shoot populations were typical for wheat (HGCA, 1998), and there was no significant increase in the number of shoots $\mathrm{m}^{-2}$ in the canopies above 350 seeds $\mathrm{m}^{-2}$. There were significantly higher numbers of shoots per plant at GS31 with reduced seed rate. The average shoot survival was low (32\%) leaving the number of ears at the low end of the target range for winter wheat as described by SylvesterBradley et al. (1997), but not atypical for a continuous wheat.

Measurements relating to final yield are shown in Table 2 and were available from two sources: (a) hand harvested $(\mathrm{HH})$ samples, supported by measures in yield components, and (b) combine harvester $(\mathrm{CH})$ measures. The $\mathrm{CH}$ measures were extracted from the raw combine harvester yield data in $20 \mathrm{~m}$ long sections, $10 \mathrm{~m}$ before and after the transect point locations. This was to encompass positioning error in the global positioning system (GPS) location and to dampen the effect of the high frequency variations in measurement of the yield-recording systems on the combine harvester (Moore, 1998).

Differences in measured yield can exist between $\mathrm{HH}$ and $\mathrm{CH}$ samples due to discrepant quadrat edge effects in the $\mathrm{HH}$ measures, which could be as much as $25 \%$ if an additional row is included or excluded, or to a lesser extent, through fewer grains being lost in comparison to the combine harvester leading to marginally higher recorded $\mathrm{HH}$ yields 
(Bloom, 1985). The $\mathrm{CH}$ yields are used in the final analysis for three reasons: wheat is harvested by commercial growers using similar combine harvesters and so results are directly comparable; the samples are taken from a larger area and less prone to localised variability. Finally, when comparing total strip responses, the $\mathrm{CH}$ measures represent the complete strip 'population' with no sampling error - only the yield meter error.

The results of the yield measurements in Table 2 reveal an actual improvement in yield (probability $p=0.052$ ) from the lowering of seed rates. The $\mathrm{CH}$ measurements indicate yields increasing from $6.0 \mathrm{t} \mathrm{ha}^{-1}$ up to $6.5 \mathrm{t} \mathrm{ha}^{-1}$. Table 2 also shows that the yield improvements were directly related to an increase in both the number of grains per ear $(p=0.016)$ and the TGW ( $p=0.136)$, each compensating for a reduction in ear numbers $(p=0.426)$. Compared to the standard practice of using 350 seeds $\mathrm{m}^{-2}$, a seed rate of 250 seeds $\mathrm{m}^{-2}$ led to a $£ 33 \mathrm{ha}^{-1}$ improvement in gross margin due to a combination of increased yield and lower seed costs. Increasing the seed rate to 450 seeds $\mathrm{m}^{-2}$ led to a gross margin penalty of $-£ 24 \mathrm{ha}^{-1}(p=0.104)$ through yield reductions and increase seed costs. Gross margins were calculated based on a seed price from Nix (2000) of $£ 220 \mathrm{t}^{-1}$ and a wheat price of $£ 65 \mathrm{t}^{-1}$.

\subsection{Onion Field 1999}

The results of from Onion Field in 1998 (ON98) demonstrated the ability to use seed rate to introduce variable plant populations in addition to that caused by inherent field variation. The plan in 1999 was to conduct a variable seed rate and $\mathrm{N}$ interaction experiment with the objective of manipulating the canopy to achieve an optimum GAI. The results from ON98 also indicate a possible benefit if a further reduction in seed rates were to be included. The ON99 experimental design included an additional lower rate strip of 150 seeds. $\mathrm{m}^{-2}$.

Table 3 shows that the four seed rates resulted in range of spring plant populations of 124256 plants $\mathrm{m}^{-2}$. Although the target seed rates were 150, 250, 350 and 450 seed $\mathrm{m}^{-2}$, the actual 
seed rates were miscalculated during drill calibration, which were estimated to be 180,300 , 420 and 540 seeds $\mathrm{m}^{-2}$. There was a significant reduction in plant population over the winter, especially at the highest seed rate. Greater reduction in plant survival at the 540 seeds $\mathrm{m}^{-2}$ resulted in an establishment of $c .50 \%$ compared to $c .70 \%$ at 180 seeds $\mathrm{m}^{-2}$. This was a consequence of severe waterlogging, caused by a failure in the drainage system. The waterlogging also severely restricted crop growth, consequently, the intended 'variable' strips received a higher, uniform dose at all timings.

Tillering was low, especially in comparison to ON98 results, resulting in rather low shoot populations (Table 3 ). Final ear populations were low, and below 400 ears $\mathrm{m}^{-2}$ at 180 seeds $\mathrm{m}^{-2}$. The results in Fig. 4, from the individual transects, showed convoluted interactions between seed rate and transect position. Because the number of individual observations for each combination of seed rate $v s$. transect-position was small, conclusions relating to transect positions must be drawn with due care.

Seed rate had little effect on final ear populations at the lower $\mathrm{N}$ rate $\left(200 \mathrm{~kg}[\mathrm{~N}] \mathrm{ha}^{-1}\right)$. However, there was a greater trend of increased ear numbers with increased seed rate $(p=0.095)$ where more $\mathrm{N}$ was applied $\left(245 \mathrm{~kg}[\mathrm{~N}] \mathrm{ha}^{-1}\right)$. Transect 2 , which was most affected by waterlogging, showed the most obvious increase in shoot and ear populations corresponding to seed rate, and the least difference due to N. Transect 1 had the highest ear populations (Fig. 8a). It also had the highest shoot count, the highest biomass at both GS30 and harvest, and gave the highest TGWs. Soil analysis revealed consistently higher levels of $\mathrm{P}, \mathrm{K}, \mathrm{Mn}, \mathrm{Cu}$ and $\mathrm{Zn}$ in Transect 1 , and this was reflected, although to a lesser extent, in tissue levels of $\mathrm{P}, \mathrm{Cu}$ and $\mathrm{Zn}$.

Grains per ear decreased with increased seed rate in all transects. Transect 1 generally had the lowest grains per ear, and also showed the least differences between seed rates, especially 
at the higher $\mathrm{N}$ rate (Fig. $8 b$ ). Field locations with the lowest ear numbers appeared to respond with higher numbers of grains per ear. There was also a greater range in compensation of grains-per-ear where ear numbers were more uniform. It was difficult to identify any clear patterns by transect in TGW.

Harvest measurements did not show a clear relationship between seed rate and final yield (Table 4). At the standard application rate of $\mathrm{N}, 200 \mathrm{~kg}[\mathrm{~N}] \mathrm{ha}^{-1}$, the highest yields were achieved at 180 seeds $\mathrm{m}^{-2}$ and 420 seeds $\mathrm{m}^{-2}$, and lower yields at 300 seeds $\mathrm{m}^{-2}$ and 540 seeds $\mathrm{m}^{-2}$. Although the effect of seed rate is inconclusive, the application of extra N $(245 \mathrm{~kg}[\mathrm{~N}]$ $\mathrm{ha}^{-1}$ ) appears to have had two effects relating to whether it was applied to the low yielding strips or to the high yielding strips. In the higher yielding strips $\left(180\right.$ and 420 seeds $\left.\mathrm{m}^{-2}\right)$ the effect was to maintain yield or to reduce it by $0.5 \mathrm{tha}^{-1}$. In the relatively lower yielding strips (300 and 540 seeds $\mathrm{m}^{-2}$ ) the application of extra $\mathrm{N}$ corresponded to an increase in yield by up to $1.5 \mathrm{t} \mathrm{ha}^{-1}$. This pattern was observed in all measures of yield: $\mathrm{HH}$ measures, complete $\mathrm{CH}$ strip averages, or $\mathrm{CH}$ averages taken at the transect positions. The low yielding areas corresponded to lower ear populations. The application of extra $\mathrm{N}$ corresponded to a higher number of ears, but not to an increase in grain numbers per ear.

Where the standard rate of $\mathrm{N}$ was applied, the lower seed rate strips produced yields that were better than or equal to the highest seed rates strips; the highest gross margin was achieved at the lowest seed rate due to a combination of an improvement in yield and associated reduced seed cost. Conversely, the addition of extra $\mathrm{N}$ corresponded to the highest yield at the highest seed rate, where the yield benefit outweighed the additional cost of extra seed and produced the highest gross margin (Table 4).

Yield measurements showed no differences between transect positions with the exception of Transect 2 where the lowest seed rate produced the lowest yields (Fig. 8d). Dropping the 
seed rate uniformly - although the better option in 3 out of 4 transects - led to a $3 \mathrm{tha}^{-1}$ reduction in yield in Transect 2.

\subsection{Onion Field 2000}

At all four seed rates, modest establishment (c.65\%) resulted in a range of plant populations of 95 to 224 plants $\mathrm{m}^{-2}$ (Table 5). To determine the required number of shoots to produce a canopy GAI of 7.0 at anthesis (GS61), an estimate of the green area per shoot (GAPS) was calculated using Eqn 1. For the purposes of calculating the target shoot numbers for the first $\mathrm{N}$ application, an estimate of shoot survival was used. Earlier results showed that shoot survival increases with decreasing plant numbers, created by varying seed rate. However, a stable rate had not been observed as the measured survival rates also varied between seasons from $30-35 \%$ in ON98 to $50-75 \%$ in ON99. As such, an average shoot survival range of $45-50 \%$, for the highest to lowest seed rate, respectively, was adopted based on work reported by Sylvester-Bradley et al. (1997).

Field observations provided an estimate of the percentage completion of the tillering phase, which was determined to be $95 \%$ complete, and assumed equal for all seed rates. Table 6 summarises the derivation of target shoot populations required at the first $\mathrm{N}$ timing for the four initial seed rates in order to achieve the GAI of 7.0 by GS61.

An ADP image was acquired on $5^{\text {th }}$ March, followed by ground survey on the $13^{\text {th }}$ March, and calibrated to produce the shoot population map shown in Fig. $5 a$. Since each seed rate resulted in different GS31 target shoot populations (Table 6), each seed rate strip required a separate classification. Figure $5 b$ shows the resulting shoot map classified into 'below target', 'on-target', and 'above-target', based on whether they were below $60 \%$, between $60 \%-95 \%$, or greater than $95 \%$ of the respective GS31 shoot targets. No significant part of the field 
exceeded the $13^{\text {th }}$ March target population which was generally below target. On this basis the field received either a standard dose of fertiliser $\mathrm{N}$, if on-target, or an increased dose if below target as shown in the schematic treatment map illustrated in Fig. 6a. Although soil N tests in February gave values for available $\mathrm{N}$ ranging between 36 and $165 \mathrm{~kg}[\mathrm{~N}] \mathrm{ha}^{-1}$, there was no pattern, therefore, the field average of $72 \mathrm{~kg}[\mathrm{~N}] \mathrm{ha}^{-1}$ was used.

For the second $\mathrm{N}$ application on the $29^{\text {th }}$ April, an ADP image was acquired on $7^{\text {th }}$ April, followed by the ground survey on the $17^{\text {th }}$ April when the field was at the beginning of stem extension (GS31). Figure $7 a$ shows a large proportion of the field below-target with a GAI in the range of 0.5-1.5. At the first application, these same areas received an increased dose and, therefore, in accordance with Table 1, now received a scheduled on-target dose. Areas on-target, with a GAI of 1.5-2.0, received a standard dose if they had received a standard dose at the first application timing, otherwise they received a reduced dose if the earlier dose was an increased dose.

The third $\mathrm{N}$ application was on $24^{\text {th }}$ May, when the crop was at GS35. The final calibrated ADP image, shown in Fig. $7 b$, estimated a significant area of the field was below the GAI threshold of 5.5 and was given extra N. The north-eastern edge of the field was above target and received zero $\mathrm{N}$ as shown in Fig. 6c. Table 7 summarises the $\mathrm{N}$ rates applied at each timing.

The results from the harvest show that the variable-rate $\mathrm{N}$ application strategy produced $0.53 \mathrm{t} \mathrm{ha}^{-1}$ more grain on average for all seed rates in comparison to the uniform standard application strategy (Table 8). Unlike the earlier experiments, the greatest yield was achieved with variable $\mathrm{N}$ at the highest seed rate of 450 seeds $\mathrm{m}^{-2}$, and not the lowest. The amount of variably applied $\mathrm{N}\left(192 \mathrm{~kg}[\mathrm{~N}] \mathrm{ha}^{-1}\right)$ required to achieve this maximum yield was essentially the same as the standard rate $\left(200 \mathrm{~kg}[\mathrm{~N}] \mathrm{ha}^{-1}\right)$. The increase in yield corresponded directly to 
the re-distribution of $\mathrm{N}$ varied spatially along the strip. At the lower seed rates, the adopted variable $\mathrm{N}$ strategy led to a greater amount of $\mathrm{N}$ being added (Table 8). Consequently, the increase in $\mathrm{N}$ cost and the corresponding smaller increase in yield led to a relatively smaller gross margin benefit, although the improvement in yield by varying $\mathrm{N}$ at all seed rates outweighed the cost of $\mathrm{N}$. This led to a range in gross margin benefit of $£ 17 \mathrm{ha}^{-1}$ to $£ 60 \mathrm{ha}^{-1}$, for 150 to 450 seed $\mathrm{m}^{-2}$, respectively (derived from Table 8).

\subsection{Far Highlands 2000}

Plant establishment was high and in the range $71 \%$ to $80 \%$ for the four seed rates, 150 to 450 seeds $\mathrm{m}^{-2}$, with autumn plant counts of 120 to 320 plants $\mathrm{m}^{-2}$, respectively, as shown in Table 9, which also summarises the derivation of shoot targets required to achieve a GAI of 6.5 at GS61.

An ADP image was acquired on the $5^{\text {th }}$ March, followed by ground survey on the $7^{\text {th }}$ March. Figure $8 a$ represents the calibrated ADP image processed to indicate shoot density at the time of the $1^{\text {st }} \mathrm{N}$ application.

The second ADP image shown in Fig. 9 was taken on 11th April when the crop was at GS30. The presence of broad-leaved weeds precluded the successful calibration of this image. This is because all actively growing vegetation contributes to the flux of reflected light from the crop canopy. It is impossible, with the two-band ADP system, to separate the combined effect on reflectance of the weed and the crop. However, the data from the ground calibration exercise was used to provide an indication of the current GAI, which was 1.3 and on-target for GS30. Consequently, and since no accurate map of spatial variation in GAI was available, the majority of the field received a uniform 'standard' dose rate of $90 \mathrm{~kg}[\mathrm{~N}] \mathrm{ha}^{-1}$, 
except for a small waterlogged area in the centre of the field shown in Fig. 9b. The application took place on the $2^{\text {nd }}$ May.

For the third $\mathrm{N}$ application, on $25^{\text {th }}$ May, the ADP image shown in Fig. $10 a$ was acquired. Broad-leaved weeds were still present and, although now controlled and dying back, an extensive ground survey was undertaken to 'replace' the image and provide sufficient data to enable the $\mathrm{N}$ management strategy to be completed fully. A total of 144 individual quadrat observations were made in the field. The high number of field observations required to replace the image data would prohibit this same approach from being used practically on the farm, but highlighted the need for effective weed management where a remotely sensed image of crop growth is to be used. The image was used to visually interpret whether the samples were representative of the broader area from which they were taken.

The combine harvest $(\mathrm{CH})$ yield results in Table 10 show that the variable rate $\mathrm{N}$ application strategy produced very similar, although marginally lower, yields on average to the standard, uniform approach. The average yield difference was less than $0.1 \mathrm{t} \mathrm{ha}^{-1}$. The highest yield was achieved at the lowest seed rate, with the variable outperforming the standard strips by $0.3 \mathrm{t} \mathrm{ha}^{-1}$. This improvement was achieved using effectively the same amount of total $\mathrm{N}$ as applied in the standard, as observed for the highest yield strips in ON00.

Table 11 presents achieved green area per shoot (GAPS) sizes from GS29 through to the target timing at GS61 (compare to Table 9). In the standard N application strips, the GAPS did not strongly relate to seed rate or initial plant population, and exceeded the target. The GAPS in the variable application strips more closely fitted the expected decline in GAPS with increasing autumn plant population.

Whilst the variable application strategy performed marginally worse than the standard, in three out of the four seed rates, the total amount of applied $\mathrm{N}$ was lower, particularly in 350 and 450 seed rate strips. This led to the variable $\mathrm{N}$ strategy producing marginally higher gross 
margins of $£ 20 \mathrm{ha}^{-1}, £ 2 \mathrm{ha}^{-1}$ and $£ 10 \mathrm{ha}^{-1}$ in the 150,350 and 450 seeds $\mathrm{m}^{-2}$ strips. The 250 seeds $\mathrm{m}^{-2}$ strip lost $£ 1 \mathrm{ha}^{-1}$.

\subsection{Environmental implications}

Whilst this project did not specifically address the environmental implications of variable nitrogen application it is possible to draw some conclusions on the potential impact of precision farming decisions on the nitrogen balance in the environment.

It was possible to calculate the potential offtake of nitrogen in the variable treatment compared to the standards for each seed rate in Onion Field, 2000 (Table 12) using the strip mean grain yields, grain and straw nitrogen content, and average fertiliser $\mathrm{N}$ application rate measured in the quadrate samples, and assuming a straw yield equal to $65 \%$ of grain yield. In the lowest seed rate, which produced only 100 plants $\mathrm{m}^{-2}$, both the uniform and variable nitrogen programmes had nitrogen offtakes which were significantly less than the amount applied, resulting in a surplus at the end of the season. At the two highest seed rates the offtakes from the variable $\mathrm{N}$ applications were higher than applied $\mathrm{N}$ resulting in a net reduction in $\mathrm{N}$ balances (similar measures were not made in Far Highlands and, so, cannot be reported). Averaged over the four seed rates, the $\mathrm{N}$ surplus for the variable treatments was $18.5 \mathrm{~kg}[\mathrm{~N}]$ $\mathrm{ha}^{-1}$ compared to $28 \mathrm{~kg}[\mathrm{~N}] \mathrm{ha}^{-1}$ for the uniform treatments. This represents a $34 \%$ reduction in the net amount of residual $\mathrm{N}$ in the soil from the variable application. This could have considerable longer term environmental significance.

\section{Discussion}

Varying seed rate led to a directly proportional response in plant and shoot populations in both fields in all years. However, plant and shoot populations obtained from equivalent seed rates differed substantially between years and between fields. Directly compensating for the 
large variation in shoot production, shoot survival compensated to produce ear populations that were consistently in the range $350-550$ ears $\mathrm{m}^{-2}$ in all years in Onion Field (ON98-00). Shoot survival was consistently higher at lower shoot populations in all cases. Although still apparent, the effect of seed rate on final ear populations was small. In FH00, the range in seed rate response on initial plant population, shoot production and survival was much greater than in ON98-00. In summary, ON98 had good plant establishment, produced the highest shoot populations with low shoot survival (31-35\%); ON99 had higher plant populations but produced the lowest shoot populations and maintained a high shoot survival (55-72\%). In ON00, plant establishment and shoot production were moderate with high shoot survival (6271\%). FH00 had good establishment, a high rate of shoot production and shoot survival and the greatest range (45-81\%). Although smaller, the effect of the different varieties would have had an impact on shoot production and survival. Results imply that seasonal factors had a bigger impact on crop structure than seed rate.

The results highlighted the potential to alter the crop structure to the benefit of final yield. The higher seed rates resulted in a greater tiller mortality rate than at the lower seed rates, which would indicate a greater level of inefficiency, although some $\mathrm{N}$ and carbohydrate may be translocated from the dying tillers (Lupton \& Pinthus, 1969). Lowering seed rates resulted in a more efficient crop structure, greater yields and improved gross margin benefits.

Compensation for the reduced plant population due to reduced seed rate was expected in the green area per shoot (GAPS). This pattern was observed more clearly in the variable $\mathrm{N}$ application strips, but not in the standard. This indicates that the variable $\mathrm{N}$ management was successful in managing the canopy size components towards the optimum, although the final GAPS exceeded the target.

Remarkably, the number of grains $\mathrm{m}^{-2}$ were relatively similar for all seed rates in all years, c.20000, with TGW generally falling in relation to increased seed rate and, consequently, 
plant/shoot populations. Lowering seed rates to below the standard practice benefited the grower by $£ 33 \mathrm{ha}^{-1}$ in ON98 through lower seed costs and an extra $0.3 \mathrm{t} \mathrm{ha}^{-1}$ yield. Moving to higher seed rates led to a net loss $\left(-£ 24 \mathrm{ha}^{-1}\right)$.

In ON99, the extra, uniform rate of $245 \mathrm{~kg}[\mathrm{~N}] \mathrm{ha}^{-1}$ compared to the standard $200 \mathrm{~kg}[\mathrm{~N}]$ $\mathrm{ha}^{-1}$ corresponded to a greater number of shoots per plant. However, the initial plant populations prior to $\mathrm{N}$ application were already higher in the ' $245 \mathrm{~kg}[\mathrm{~N}] \mathrm{ha}^{-1}$ strip, therefore, conclusions regarding the effect of $\mathrm{N}$ on shoot population should be drawn carefully from this.

Final yields in ON99 were unusual due to isolated areas of severe waterlogging showing an irregular response to seed rate. In areas similar to the 150 seed rate in Transect 2, the best management combination would appear to have been to increase seed rate to 450 seed $\mathrm{m}^{-2}$ and to increase the levels of $\mathrm{N}$ above the standard rate to $245 \mathrm{~kg}[\mathrm{~N}] \mathrm{ha}^{-1}$. By dropping to the lowest seed rate, which produced the best yields in all other transects, there was a considerable yield penalty of $c .3 \mathrm{t} \mathrm{ha}^{-1}$ and lost profit of $£ 180 \mathrm{ha}^{-1}$. This area of waterlogging represented $20 \%$ of the total field area, i.e. a total missed benefit of up to $£ 500$.

The results from 2000 show benefits from this approach over and above standard uniform production practices. Variable $\mathrm{N}$ application could prove to be a realistic prospect for the future of cereal farming.

The ADP data were successfully collected and ground calibration was completed efficiently to provide accurate, near real-time shoot density maps and GAI maps (Wood et al., 2003). However, as in all areas of precision farming strategies, the common problems facing the grower, e.g. weeds and drainage, which caused problems in the experiments, pest and diseases, must first be managed effectively before the benefits of precision management can be realised (Godwin et al., 2003). Better general management is also essential for the 
integration of remote sensing technologies into the farm management system - particularly to avoid weed infestation, which interferes with the crop reflectance signal.

The first objective to managing the canopy was to control shoot development. Given the different initial plant populations in $\mathrm{ONOO}$ and $\mathrm{FH} 00$ the final shoot density required to achieve the target GAI was estimated objectively. The results from the standard strips show that, when uncorrected by $\mathrm{N}$ the final ear population compensated to within $c .100$ ears $\mathrm{m}^{-2}$ of the optimal densities for light interception as proposed by Stokes et al. (1998). Moreover, the intervention through $\mathrm{N}$ management tended the crop structure much closer to this optimum. In FH00 the difference between the standard and the variable strips was much less, although the variable strip always tended closer towards the optimum, as shown Table 11.

There was a tendency for greater levels of $\mathrm{N}$ to be applied with decreasing seed rate over and above the standard rate. This was because, by the third $\mathrm{N}$ application, ON00 was below target in parts of the field. At the lower seed rates greater portions of the strips were below target compared with higher seed rates $-c .90 \%$ of the 150 seed rate strip was below target. These areas received extra N. This was similar for FH00. However, due to better establishment in FH00, the relative amounts of applied N compared to the standard were the opposite in ON99: the higher seed rates strips were over-target and received zero $\mathrm{N}$ in places. Again, the tendency here was for greater levels of $\mathrm{N}$ being applied with decreasing seed rate.

Where the crop tended to be over-target during canopy expansion - corresponding to 'total applied N' values that were considerably less than the standard - there was a penalty in yield. Typically, the crop produced better or equivalent yields from variably applied N. The following effects on gross margin can be noted: 
The highest gross margins were achieved where the total applied $\mathrm{N}$ was similar to the standard: $£ 60 \mathrm{ha}^{-1}$ in ON00 at 450 seeds $\mathrm{m}^{-2}$; and $£ 20 \mathrm{ha}^{-1}$ in FH00 at 150 seeds $\mathrm{m}^{-2}$.

In FH00 the final yields were very similar, c.7.9 $\mathrm{t} \mathrm{ha}^{-1}$, at all seed rates in both the standard and variable strips. However, the amount of $\mathrm{N}$ required to acheived this yield varied considerably, especially in the 350 and 450 seeds $\mathrm{m}^{-2}$ strips. Except at the lowest seed rate, the gross margins for the variable $\mathrm{N}$ strips were very similar to their correspoding standard.

Although $\mathrm{N}$ fertiliser costs were greater at the lower seed rates in ON00, the positive effect on yield meant that yield benefits outweighed seed and $\mathrm{N}$ costs by $£ 17 \mathrm{ha}^{-1}$ in the 150 seeds $\mathrm{m}^{-2}$ strip, and by $£ 38 \mathrm{ha}^{-1}$ in the 250 seeds $\mathrm{m}^{-2}$ strip.

\section{Conclusions}

In order to manage a canopy effectively, an accurate and timely measure of canopy size is required. Aerial digital photography techniques provided an accurate and timely method for assessing canopy size at the three $\mathrm{N}$ application dates during the period from mid tillering to the end of stem extension. The airborne remote sensing technique is suitable for adoption commercially at an economic rate.

Variations in seed rate led to proportional variations in plant density. Underlying soil variation also affected establishment and, thus, contributed to variations in plant density. Lowering seed rate below standard farm practice led to marginally higher numbers of tillers per plant and higher shoot survival. From different initial plant populations, the wheat compensated and tended final ear populations towards a similar density relative to maximum shoot populations at growth stage GS30.

Variable rate applications of $\mathrm{N}$ based upon real-time assessments of canopy size was successful in increasing the gross margin for all four seed rates in Onion Field and for two 
out of four in Far Highlands Field with the remaining two being effectively the same as the standard approach to within $£ 1-2 \mathrm{ha}^{-1}$.

The highest gross margins came from variable strips where the total amount of applied $\mathrm{N}$ was similar to the standard, indicating a more efficient use of $\mathrm{N}$ when targeted according to real-time measures of canopy size.

Greater or equivalent yields were achieved by the variable N strategy. However, yields were lower than the standard in strips where the total amount of $\mathrm{N}$ was significantly reduced in an attempt to 'hold back' over-sized canopies. However, even in these situations the gross margins exceeded those achieved through the standard application of $\mathrm{N}$ because of lower fertiliser costs and only small associated yield penalties.

At all four seed rates in Onion Field, the variable N strategy out-performed the uniform applications, increasing the gross margins by up to an extra $£ 60 \mathrm{ha}^{-1}$. In Far Highlands Field, the variable application outperformed the uniform, in three out of four seed rates, by up to $£ 20 \mathrm{ha}^{-1}$. The strips where the standard produced higher returns only managed an improvement of $£ 1 \mathrm{ha}^{-1}$.

Considering the environmental implications, a simple nitrogen balance calculation showed that in addition to an increase in yield, the spatially variable application of nitrogen can have an overall effect of reducing the nitrogen surplus by approximately one third.

\section{Acknowledgements}

The authors would like to thank the sponsors of this work, Home Grown Cereals Authority, Hydro-Agri and AGCO Ltd., for their support, and their collaborators, Arable Research Centres and Shuttleworth Farms. We would also like to acknowledge the assistance of Dr David Pullen and Dr Nicola Cosser in developing the research programme, and Robert 
Walker for implementing the treatments and harvesting the experiments. Thanks must also be extended to Messrs F. and J. Wilson, who farm Onion Field, and to B. Welti who farms Far Highlands, for their co-operation. Thank you also to Lely (UK) Ltd for the loan of a variablerate combination seed drill. 


\section{References}

Blackmer T M; Schepers J S; Varvel G E (1994). Light reflectance compared with other nitrogen stress measurements in corn leaves. Agronomy Journal, 86, 934-938

Blackmer T M; Schepers J S; Varvel G E; Walter-Shea E A (1996). Nitrogen deficiency detection using reflected shortwave radiation from irrigated corn canopies. Agronomy Journal, 88(1), 1-5

Bloom T M (1985). Bias in the measurement of crop performance. Aspects of Applied Biology 10, Field trial methods and data handling, 241-258

Carr P M; Carlson G R; Jacosen J S; Nielson G A; Skogley E O (1991), Farming soils, not fields: a strategy for increasing fertiliser profitability. Journal of Production Agriculture, 4(1), 57-61

Chapman S C; Barreto H J (1997). Using a chlorophyll meter to estimate specific leaf nitrogen of tropical maize during vegetative growth. Agronomy Journal, 89, 557-562

\section{Earl R; Taylor J C; Wood G A; Bradley R I; Welsh T Waine J P; Knight S M; Godwin} R J (2003). Soil factors and their influence on within-field crop variability, part I: field observation of soil variation. Biosystems Engineering

Godwin R J; Richards T E; Wood G.A; Welsh J P; Knight S M (2003). An economic analysis of the potential for precision farming in UK cereal production. Biosystems Engineering

Goward S N; Markham B; Dye D G; Dulaney W; Yang J (1991). Normalised difference vegetation index measurements from the advanced very high resolution radiometer. Remote Sensing of Environment, 35, 257-277

Graham R W (1994). Kodak digital cameras for small format aerial photography, Photogrammetric Record, 15, 325-327 
HGCA (1998). Wheat Growth Guide. Home Grown Cereals Authority, Caledonia House, 223 Pentonville Road, London N1 9HY

Kitchen N R; Hughes D F; Sudduth K A; Birrell S J (1995). Comparison of variable rate to single rate nitrogen fertiliser application: corn production and residual soil $\mathrm{NO}_{3}-\mathrm{N}$. In: Proceedings of the Second International Conference on Site-Specific Management for Agricultural Systems Minneapolis, Minnesota, March 27-30, 1994, (Robert P C; Rust R H; Larson W E eds.), Madison, Wisconsin, USA. 427-439

Lupton F G H; Pinthus M J. Carbohydrate translocation from small tillers to spikeproducing shoots in wheat. Nature, 221, 483-484.

Moore M (1998). An investigation into the accuracy of yield maps and their subsequent use in crop management. PhD Thesis, Cranfield University, Silsoe, Bedfordshire, MK45 4DT, UK

Mulla D J; Bhatti A U; Hammond M W; Benson J A (1992). A comparison of winter wheat yield and quality under uniform versus spatially variable fertiliser management. Agriculture, Ecosystems and Environment, 38, 301-311

Nolan S C; Heaney D J; Goddard T W; Penney D C; McKenzie R C (1995). Variation in fertiliser response across soil landscapes. In: Proceedings of the Second International Conference on Site-Specific Management for Agricultural Systems Bloomington, Minneapolis March 27-30, 1994, (Robert P C; Rust R H; Larson W E eds.), Madison, Wisconsin, USA

Nix J (2000). Farm Management Pocket Book. Wye College Press, Wye, UK

Spink J H; Semere T; Sparkes D L; Whaley J M; Foulkes M J; Clare R W; Scott R K (2000). Effect of sowing date on the optimum plant density in winter wheat. Annals of Applied Biology, 137, 179-188 
Stokes D T; Sylvester-Bradley R; Scott R K; Clare R; Hopkinson J; Milford G F J;

Salmon S E (1998). An integrated approach to nitrogen nutrition for wheat. Project Report No. 159, Home Grown Cereals Authority, Caledonia House, 223 Pentonville Road, London N1 9HY

Sylvester-Bradley R; Spink J; Foulkes M J; Bryson R J; Scott R K; Stokes D T; King J A; Parish D; Paveley N D; Clare R W (2000). Sector challenge project - canopy management in practice. Home Grown Cereals Authority, Crop Management into the Millennium Conference, 6-7 January 2000, Home-Grown Cereals Authority, London, pp. $11 / 1-14$

Vetsch J A; Malzer G L; Robert P C; Huggins D R (1995). Nitrogen specific management by soil condition: managing fertiliser nitrogen in corn. In: Proceedings of the Second International Conference on Site-Specific Management for Agricultural Systems, Bloomington, Minneapolis, March 27-30, 1994 (Robert P C; Rust R H; Larson W E eds), Madison, Wisconsin, USA. 465-473

Taylor J C; Wood G A; Thomas G (1997) Mapping yield potential with remote sensing. Precision Agriculture '97, Vol. 2, BIOS Scientific Publishers Limited, 1997, Ed John Stafford, pp713-721.

Taylor J C; Earl R; Wood G A; Godwin R J (2003) Soil Factors and their influence on within-field crop variability, part II: spatial analysis and determination of management zones, Biosystems Engineering

Welsh J P; Wood G A; Godwin R J; Taylor J C; Earl R; Blackmore S; Knight S (2003a). Developing strategies for spatially variable nitrogen application in cereals, part I: winter barley, Biosystems Engineering 
Welsh J P; Wood G A; Godwin R J; Taylor J C; Earl R; Blackmore S; Knight S (2001b). Developing strategies for spatially variable nitrogen application in cereals, part II: wheat, Biosystems Engineering

Wood G A; Thomas G; Taylor J C (1998) Developing calibration techniques to map crop variation in yield potential using remote sensing. $4^{\text {th }}$ International Conference on Precision Agriculture. (Robert P C; Rust R H; Larson W E eds) ASA, CSSA, SSSA, Madison, USA, pp881-886

Wood G A; Taylor J C; Godwin R J (2003). Calibration methodology for mapping withinfield crop variability using remote sensing. Biosystems Engineering

Whaley J M; Sparkes D L; Foulkes M J; Spink J H; Semere T; Scott R K (2000). The physiological response of winter wheat to reductions in plant density. Annals of Applied Biology, 137, 165-177

\section{Appendix}

Appendix tables from Fig.s and tables. 
Tables and Figs for:

Real-time Measures of Canopy Size as a Basis for Spatially Varying Nitrogen Applications to Winter Wheat Sown at Different Seed Rates

G. A. Wood ${ }^{1}$; J. P. Welsh ${ }^{1}$; R. J. Godwin ${ }^{1}$; .J. C. Taylor ${ }^{1}$; R. Earl ${ }^{1}$; S. M. Knight ${ }^{2}$ 
Table 1.

Main nitrogen dose strategy (GS31) - increased or decreased doses are based on GAI and modified according to previous levels of applied $\mathbf{N}$.

\begin{tabular}{cllc}
\hline $\begin{array}{c}\text { GAI below } \\
\text { target }\end{array}$ & $\begin{array}{c}\text { GAI on } \\
\text { target }\end{array}$ & $\begin{array}{c}\text { GAI above } \\
\text { target }\end{array}$ \\
\hline $\begin{array}{c}\text { If the early dose was } \\
\text { reduced (or zero) }\end{array}$ & Increase & Increase & $\begin{array}{c}\text { On-target } \\
\text { dose }\end{array}$ \\
\hline $\begin{array}{c}\text { If the early dose was at } \\
\text { the scheduled standard } \\
\text { rate }\end{array}$ & Increase & $\begin{array}{c}\text { On-target } \\
\text { dose }\end{array}$ & Reduce \\
\hline $\begin{array}{c}\text { If the early dose was at } \\
\text { an increased rate }\end{array}$ & $\begin{array}{c}\text { On-target } \\
\text { dose }\end{array}$ & Reduce & Reduce \\
\hline
\end{tabular}


Table 2.

Nitrogen fertilizer application rates $\left(\mathrm{kg} \mathrm{N} \mathrm{ha}^{-1}\right)$ applied to each canopy size category, organised by application timing and field site.

\begin{tabular}{lcccc} 
& \multicolumn{4}{c}{ Onion Field (ONO0) } \\
\cline { 2 - 5 } & Standard & \multicolumn{3}{c}{ Variable strips } \\
\cline { 2 - 5 } & & below-target & on-target & above-target \\
\cline { 2 - 5 } Ist N (tillering) & 50 & 94 & 50 & $\mathrm{n} / \mathrm{a}$ \\
Main N (GS31) & 90 & 90 & $90 / 65$ & $\mathrm{n} / \mathrm{a}$ \\
Final N (GS33) & 60 & 90 & 40 & 0 \\
\hline
\end{tabular}

*n/a: not applicable since no areas of crop were in this category

\begin{tabular}{lcccc}
\hline & \multicolumn{4}{c}{ Far Highlands (FHOO) } \\
\cline { 2 - 5 } & Standard & \multicolumn{3}{c}{$\begin{array}{c}\text { Variable } \\
\text { strips }\end{array}$} \\
\cline { 2 - 5 } & & below-target & on-target & above-target \\
\cline { 2 - 5 } 1st N (tillering) & 40 & 70 & 40 & 0 \\
Main N (GS31) & 90 & $\mathrm{n} / \mathrm{a}$ & $90 / 120$ & $\mathrm{n} / \mathrm{a}$ \\
Final N (GS33) & 70 & 70 & 40 & 0 \\
\hline
\end{tabular}

${ }^{*}$ n/a: not applicable since no areas of crop were in this category 
Table 3.

Target shoot populations at the $1^{\text {st }} \mathrm{N}$ timing based on estimates of final ear populations (GS61) derived from measures of autumn plant density, predicted green area per shoot (GAPS), shoot survival and percentage completion of tillering for four initial seed rates in Onion Field.

\begin{tabular}{|c|c|c|c|c|c|c|c|c|}
\hline $\begin{array}{l}\text { Initial seed- } \\
\quad \text { rate } \\
\left(\text { seeds. }{ }^{-2}\right)\end{array}$ & $\begin{array}{c}\text { Autumn } \\
\text { Plants } m^{-2}\end{array}$ & $\begin{array}{c}\text { Predicted }^{*} \\
\text { GAPS }\left(\mathrm{cm}^{2}\right) \\
\text { at } G S 61\end{array}$ & $\begin{array}{c}\text { Target GAI } \\
\text { at GS61 }\end{array}$ & $\begin{array}{c}\text { Target } \\
\text { shoots m-2 } \\
\text { at GS61 }\end{array}$ & $\begin{array}{l}\text { \% Shoot } \\
\text { Survival }\end{array}$ & $\begin{array}{c}\text { Target } \\
\text { shoots } m^{-2} \\
\text { at GS31 }\end{array}$ & $\begin{array}{c}\% \\
\text { Tillered } \\
\text { by } 1 \text { st } N\end{array}$ & $\begin{array}{c}\text { Target } \\
\text { shoots } m^{-2} \\
1 \text { st } N \\
\text { GS } 25-27\end{array}$ \\
\hline 150 & 100 & 140 & 7.0 & 500 & 52 & 960 & 95 & 910 \\
\hline 250 & 143 & 130 & 7.0 & 540 & 51 & 1060 & 95 & 1000 \\
\hline 350 & 177 & 130 & 7.0 & 540 & 49 & 1100 & 95 & 1050 \\
\hline 450 & 220 & 120 & 7.0 & 580 & 47 & 1250 & 95 & 1190 \\
\hline
\end{tabular}


Table 4.

Target shoot populations at the $1^{\text {st }} \mathrm{N}$ timing based on estimates of final ear populations (GS61) derived from measures of autumn plant density, predicted green area per shoot (GAPS), shoot survival and percentage completion of tillering for four initial seed rates in Far Highlands.

\begin{tabular}{ccccccccc}
\hline $\begin{array}{c}\text { Initial seed- } \\
\text { rate } \\
\left(\text { seeds.m }^{-2}\right)\end{array}$ & $\begin{array}{c}\text { Autumn } \\
\text { Plants } \\
m^{-2}\end{array}$ & $\begin{array}{c}\text { Predicted } \\
\text { GAPS }\left(\mathrm{cm}^{2}\right) \\
\text { at GS61 }\end{array}$ & $\begin{array}{c}\text { Target } \\
\text { GAI at } \\
\text { GS61 }\end{array}$ & $\begin{array}{c}\text { Target } \\
\text { shoots } \\
\mathrm{m}^{-2} \text { at } \\
\text { GS61 }\end{array}$ & $\begin{array}{c}\text { \% Shoot } \\
\text { Survival }\end{array}$ & $\begin{array}{c}\text { Target } \\
\text { shoots } m^{-2} \\
\text { at GS31 }\end{array}$ & $\begin{array}{c}\text { Tillered } \\
\text { by 1st N }\end{array}$ & $\begin{array}{c}\text { Target shoots } \\
m^{-2} 1 \text { st } N \\
\text { GS25-27 }\end{array}$ \\
\hline 150 & 120 & 130 & 6.5 & 500 & 50 & 1000 & 95 & 950 \\
250 & 195 & 120 & 6.5 & 540 & 49 & 1100 & 95 & 1050 \\
350 & 240 & 120 & 6.5 & 540 & 47 & 1150 & 95 & 1100 \\
450 & 320 & 110 & 6.5 & 590 & 45 & 1310 & 95 & 1250 \\
\hline
\end{tabular}


Table 5.

Nitrogen balance for Onion Field, 2000

Seed Rate $\quad N \quad$ Yield Grain N Straw N NOfftake NOfftake N Offtake $\quad N$ (seeds $\mathrm{m}^{-2}$ ) Applied $\left(t \mathrm{ha}^{-1}\right) \quad(\%) \quad(\%)$ Grain Straw Total Balance

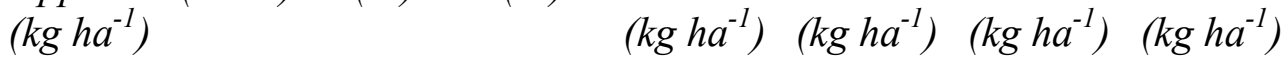

\begin{tabular}{ccccccccc}
\hline $150 \mathrm{~V}$ & 243 & 6.33 & 2.34 & 0.53 & 148.1 & 24.7 & 172.8 & 70.2 \\
$150 \mathrm{~S}$ & 200 & 5.96 & 2.23 & 0.59 & 132.9 & 20.9 & 153.8 & 46.2 \\
& & & & & & & & \\
$250 \mathrm{~V}$ & 227 & 7.18 & 2.38 & 0.5 & 170.9 & 29.4 & 200.3 & 26.7 \\
$250 \mathrm{~S}$ & 200 & 6.65 & 2.31 & 0.64 & 153.6 & 21.3 & 174.9 & 25.1 \\
& & & & & & & & \\
$350 \mathrm{~V}$ & 188 & 6.85 & 2.42 & 0.55 & 165.8 & 30.1 & 195.9 & -7.9 \\
$350 \mathrm{~S}$ & 200 & 6.37 & 2.34 & 0.68 & 149.1 & 22.9 & 172 & 28 \\
& & & & & & & \\
$450 \mathrm{~V}$ & 192 & 7.47 & 2.33 & 0.5 & 174 & 32.9 & 206.9 & -14.9 \\
$450 \mathrm{~S}$ & 200 & 6.72 & 2.46 & 0.67 & 165.3 & 21.5 & 186.8 & 13.2 \\
\hline $\mathrm{V}=$ Variable N-rate; S $=$ Standard, uniform N-rate & & &
\end{tabular}


Table A1a.

Plant establishment, shoot development and yield components at three different seed rates in $0 \mathrm{N98}$

\begin{tabular}{|c|c|c|c|c|c|c|c|c|c|c|}
\hline \multirow[t]{2}{*}{ Seeds $m^{-2}$} & \multicolumn{2}{|c|}{$\begin{array}{c}\text { Plant number } \\
\quad\left(\text { plants } \mathrm{m}^{-2}\right)\end{array}$} & \multirow{2}{*}{$\begin{array}{c}\text { Shoots } \\
m^{-2} \\
(G S 31)\end{array}$} & \multirow[t]{2}{*}{$\begin{array}{c}\text { Ears } \\
m^{-2}\end{array}$} & \multirow[t]{2}{*}{$\begin{array}{l}\text { Grains } \\
\text { per ear }\end{array}$} & \multirow[t]{2}{*}{$T G W(g)$} & \multirow{2}{*}{$\begin{array}{c}\text { Yield (t } \\
\left.h a^{-1}\right) \\
(H H)\end{array}$} & \multirow{2}{*}{$\begin{array}{c}\text { Yield (t ha } \\
\text { l) } \\
(\mathrm{CH})\end{array}$} & \multirow{2}{*}{$\begin{array}{c}\text { Gross } \\
\text { Margin } \\
\text { CH (£) }\end{array}$} & \multirow{2}{*}{$\begin{array}{c}\text { Rel. } G M \\
(350 S) \\
C H\left(£ h a^{-1}\right)\end{array}$} \\
\hline & Autumn & Spring & & & & & & & & \\
\hline 250 & 192 & 162 & 1142 & 405 & 49.2 & 40.5 & 8.1 & 6.5 & 313 & 33 \\
\hline 350 & 260 & 203 & 1380 & 419 & 48.7 & 39.2 & 8.0 & 6.2 & 280 & 0 \\
\hline 450 & 350 & 243 & 1409 & 434 & 44.8 & 38.5 & 7.5 & 6.0 & 256 & -24 \\
\hline $\mathrm{P}$ & $<0.001$ & $<0.001$ & $<0.001$ & 0.426 & 0.016 & 0.136 & 0.608 & 0.052 & $<0.001$ & \\
\hline
\end{tabular}


Table A1b.

Biomass measurements at three different seed rates in ON98

\begin{tabular}{ccccc}
\hline $\begin{array}{c}\text { Seeds } m^{-} \\
2\end{array}$ & $\begin{array}{c}\text { GS30 bio }(t \\
\left.h a^{-1}\right)\end{array}$ & $\begin{array}{c}\text { biomass per shoot } \\
(\mathrm{g})\end{array}$ & $\begin{array}{c}\text { Harvest biomass }(t \\
\left.\mathrm{ha}^{-1}\right)\end{array}$ & $\begin{array}{c}\text { biomass per ear } \\
(\mathrm{g})\end{array}$ \\
\hline 250 & 1.40 & 0.126 & 16.2 & 3.98 \\
350 & 1.85 & 0.132 & 16.1 & 3.78 \\
450 & 1.86 & 0.132 & 15.6 & 3.59 \\
\hline
\end{tabular}


Table A2a.

Plant establishment, shoot development and yield components at four different seed rates and two nitrogen rates in ON99

\begin{tabular}{|c|c|c|c|c|c|c|c|c|c|c|c|c|}
\hline \multirow{3}{*}{$\begin{array}{l}\text { Seeds } \\
m^{-2}\end{array}$} & \multirow{2}{*}{\multicolumn{2}{|c|}{$\begin{array}{l}\text { Plant number } \\
\text { (plants } m^{-2} \text { ) }\end{array}$}} & \multirow{3}{*}{$\begin{array}{c}{\text { Ears } m^{-2}} \\
(G S 31)\end{array}$} & \multirow{3}{*}{$\begin{array}{l}\text { Grains } \\
\text { per ear }\end{array}$} & \multirow{3}{*}{$\begin{array}{c}T G W \\
(g)\end{array}$} & \multirow{3}{*}{$\begin{array}{c}\text { Plant } \\
\text { number } \\
\text { (plants } \\
m^{-2} \text { ) }\end{array}$} & \multirow{2}{*}{\multicolumn{3}{|c|}{ Shoots $m^{-2}$}} & \multirow{3}{*}{ Ears $m^{-2}$} & \multirow{3}{*}{$\begin{array}{l}\text { Gra } \\
\text { ins } \\
\text { per } \\
\text { ear }\end{array}$} & \multirow{3}{*}{$\begin{array}{c}T G W \\
(g)\end{array}$} \\
\hline & & & & & & & & & & & & \\
\hline & Autumn & Spring & & & & & Autumn & Spring & (GS31) & & & \\
\hline 180 & 157 & 124 & 478 & 343 & 55 & 42.8 & 164 & 141 & 582 & 355 & 52 & 43.5 \\
\hline 300 & 271 & 198 & 653 & 384 & 50 & 40.8 & 288 & 200 & 622 & 417 & 52 & 41.1 \\
\hline 420 & 332 & 214 & 681 & 447 & 47 & 41.7 & 373 & 245 & 671 & 453 & 46 & 40.4 \\
\hline 540 & 425 & 256 & 728 & 399 & 43 & 41.4 & 464 & 264 & 840 & 486 & 42 & 43.1 \\
\hline $\mathrm{P}$ & $<0.001$ & $<0.001$ & 0.168 & 0.030 & $<0.001$ & 0.746 & $<0.001$ & $<0.001$ & 0.155 & 0.118 & $\begin{array}{c}0.15 \\
0\end{array}$ & 0.279 \\
\hline
\end{tabular}


Table A2b.

Biomass measurements at four different seed rates in ON99

\begin{tabular}{ccccc}
\hline Seeds $m^{-2}$ & GS30 bio $\left(\mathrm{tha}^{-1}\right)$ & biomass per shoot $(\mathrm{g})$ & Harvest biomass $\left(\mathrm{t} \mathrm{ha^{-1 }}\right)$ & biomass per ear $(\mathrm{g})$ \\
\hline 180 & 0.73 & 0.138 & 13.07 & 3.74 \\
300 & 0.77 & 0.121 & 13.16 & 3.23 \\
420 & 0.86 & 0.127 & 13.86 & 3.08 \\
540 & 1.05 & 0.134 & 12.85 & 2.91 \\
\hline
\end{tabular}


Table A2c.

Final yield and related economics in ON99 at the four different seed rates and two nitrogen rates

\begin{tabular}{|c|c|c|c|c|c|c|c|c|c|c|}
\hline \multirow[b]{3}{*}{$\begin{array}{l}\text { Seeds } \\
m^{-2}\end{array}$} & \multirow[b]{3}{*}{$\begin{array}{c}\text { Seed } \\
\text { costs }(£ \\
\left.h a^{-1}\right)\end{array}$} & \multirow[b]{3}{*}{$\begin{array}{c}\text { Application } \\
\text { costs }\end{array}$} & \multicolumn{4}{|c|}{ Standard N $\left(200 \mathrm{~kg} \mathrm{~N} \mathrm{ha}^{-1}\right)$} & \multicolumn{4}{|c|}{ Standard N (200 $\left.\mathrm{kg} \mathrm{N} \mathrm{ha}^{-1}\right)$} \\
\hline & & & & & $\begin{array}{c}\text { Gross } \\
\text { margin }\end{array}$ & $\begin{array}{c}\text { Rel, GM } \\
\text { (350S) }\end{array}$ & & & $\begin{array}{c}\text { Gross } \\
\text { margin }\end{array}$ & $\begin{array}{c}\text { Rel, GM } \\
(350 S)\end{array}$ \\
\hline & & & $\begin{array}{l}N \text { costs } \\
\left(£ h a^{-1}\right)\end{array}$ & $\begin{array}{c}\text { Yield }(t \\
\left.h a^{-1}\right)\end{array}$ & $\begin{array}{c}\text { Combine } \\
\left(£ h a^{-1}\right)\end{array}$ & $\begin{array}{c}\text { Combine } \\
\left(£ h a^{-1}\right)\end{array}$ & $\begin{array}{l}N \text { costs } \\
\left(£ h a^{-1}\right)\end{array}$ & $\begin{array}{c}\text { Yield }(t \\
\left.h a^{-1}\right)\end{array}$ & $\begin{array}{c}\text { Combine } \\
\left(£ h a^{-1}\right)\end{array}$ & $\begin{array}{c}\text { Combine } \\
\left(£ h a^{-1}\right)\end{array}$ \\
\hline 180 & 17.4 & 21 & 60 & 7.12 & 364 & 61 & 74 & 6.33 & 321 & 17 \\
\hline 300 & 29 & 21 & 60 & 5.53 & 249 & -54 & 74 & 6.01 & 288 & -15 \\
\hline 420 & 40.7 & 21 & 60 & 6.54 & 303 & 0 & 74 & 6.47 & 306 & 3 \\
\hline 540 & 52.3 & 21 & 60 & 5.63 & 233 & -71 & 74 & 7.52 & 363 & 60 \\
\hline $\mathrm{P}$ & & & 60 & 0.009 & 0.004 & & & 0.140 & 0.277 & \\
\hline
\end{tabular}


Table A3a.

Plant establishment, shoot development and yield components at four different seed rates with variable rate vs. uniform, standard rate $\mathrm{N}$ applications in $\mathrm{ON00}$

\begin{tabular}{|c|c|c|c|c|c|c|c|c|c|c|c|c|}
\hline \multirow{3}{*}{$\begin{array}{l}\text { Seeds } \\
m^{-2}\end{array}$} & \multicolumn{6}{|c|}{$\begin{array}{c}\text { Best Farm Practice - Uniform } \\
\text { Nitrogen }\end{array}$} & \multicolumn{6}{|c|}{ Precision Farming - Variable Nitrogen } \\
\hline & \multicolumn{2}{|c|}{$\begin{array}{l}\text { Plant number } \\
\left(\text { plants } \mathrm{m}^{-2}\right)\end{array}$} & \multirow{2}{*}{$\begin{array}{c}\begin{array}{c}\text { Shoots } \\
m^{-2}\end{array} \\
(G S 31)\end{array}$} & \multirow{2}{*}{$\begin{array}{c}\text { Ears } \\
m^{-2}\end{array}$} & \multirow{2}{*}{$\begin{array}{l}\text { Grains } \\
\text { per ear }\end{array}$} & \multirow{2}{*}{$\begin{array}{l}T G W \\
(g)\end{array}$} & \multicolumn{2}{|c|}{$\begin{array}{l}\text { Plant number } \\
\text { (plants } \mathrm{m}^{-2} \text { ) }\end{array}$} & \multirow{2}{*}{$\begin{array}{c}\begin{array}{c}\text { Shoots } \\
m^{-2}\end{array} \\
(G S 31)\end{array}$} & \multirow{2}{*}{$\begin{array}{c}\text { Ears } \\
m^{-2}\end{array}$} & \multirow{2}{*}{$\begin{array}{l}\text { Grains } \\
\text { per ear }\end{array}$} & \multirow{2}{*}{$\begin{array}{c}T G W \\
(g)\end{array}$} \\
\hline & Autumn & Spring & & & & & Autumn & Spring & & & & \\
\hline 150 & 95 & 97 & 596 & 425 & 45 & 39 & 105 & 115 & 725 & 514 & 43 & 40 \\
\hline 250 & 148 & 131 & 727 & 439 & 39 & 40 & 138 & 127 & 739 & 475 & 43 & 37 \\
\hline 350 & 184 & 155 & 827 & 495 & 38 & 40 & 170 & 153 & 817 & 589 & 37 & 38 \\
\hline 450 & 224 & 171 & 831 & 519 & 39 & 36 & 217 & 179 & 1022 & 550 & 38 & 35 \\
\hline
\end{tabular}


Table A3b.

Biomass measurements at four different seed rates in ONO0

\begin{tabular}{ccccc}
\hline Seeds $\mathrm{m}^{-2}$ & $\begin{array}{c}\text { GS30 biomass } \\
\left(\mathrm{t} \mathrm{ha} \mathrm{h}^{-1}\right)\end{array}$ & $\begin{array}{c}\text { Biomass per } \\
\text { shoot }(\mathrm{g})\end{array}$ & $\begin{array}{c}\text { Harvest } \\
\text { biomass }\left(\mathrm{t} \mathrm{ha} \mathrm{a}^{-1}\right)\end{array}$ & $\begin{array}{c}\text { Biomass per } \\
\text { ear }(\mathrm{g})\end{array}$ \\
\hline 150 & 0.95 & 0.144 & 17.02 & 3.63 \\
250 & 0.95 & 0.13 & 14.94 & 3.27 \\
350 & 1.09 & 0.133 & 17.42 & 3.21 \\
450 & 1.43 & 0.154 & 15.82 & 2.96 \\
\hline
\end{tabular}


Table A3c.

Final yield and related economics in $\mathrm{ONOO}$ at four different seed rates with variable rate vs. uniform, standard rate $\mathbf{N}$ applications

\begin{tabular}{|c|c|c|c|c|c|c|c|c|c|c|}
\hline \multirow[b]{3}{*}{$\begin{array}{l}\text { Seeds } \\
m^{-2}\end{array}$} & \multirow[b]{3}{*}{$\begin{array}{c}\text { Seed } \\
\text { costs }(£ \\
\left.h a^{-1}\right)\end{array}$} & \multirow[b]{3}{*}{$\begin{array}{c}\text { Application } \\
\text { costs }\end{array}$} & \multicolumn{4}{|c|}{ Standard N } & \multicolumn{4}{|c|}{ Variable $N$} \\
\hline & & & & & $\begin{array}{c}\text { Gross } \\
\text { margin }\end{array}$ & $\begin{array}{c}\text { Rel, GM } \\
\text { (350S) }\end{array}$ & & & $\begin{array}{c}\text { Gross } \\
\text { margin }\end{array}$ & $\begin{array}{c}\text { Rel, GM } \\
\text { (350S) }\end{array}$ \\
\hline & & & $\begin{array}{c}\text { Yield (t } \\
\left.h a^{-1}\right)\end{array}$ & $\begin{array}{l}N \text { costs } \\
\left(£ h a^{-1}\right)\end{array}$ & $\begin{array}{c}\text { Combine } \\
\left(£ h a^{-1}\right)\end{array}$ & $\begin{array}{c}\text { Combine } \\
\left(£ h a^{-1}\right)\end{array}$ & $\begin{array}{c}\text { Yield }(t \\
\left.h a^{-1}\right)\end{array}$ & $\begin{array}{l}N \text { costs } \\
\left(£ h a^{-1}\right)\end{array}$ & $\begin{array}{l}\text { Combine } \\
\left(£ h a^{-1}\right)\end{array}$ & $\begin{array}{c}\text { Combine } \\
\left(£ h a^{-1}\right)\end{array}$ \\
\hline 150 & 14 & 21 & 5.9 & 60 & 349 & -54 & 6.3 & 73 & 366 & -37 \\
\hline 250 & 23 & 21 & 6.6 & 60 & 394 & -9 & 7.2 & 68 & 432 & 29 \\
\hline 350 & 31 & 21 & 6.9 & 60 & 403 & 0 & 7.2 & 56 & 434 & 31 \\
\hline 450 & 40 & 21 & 6.7 & 60 & 381 & -22 & 7.5 & 58 & 441 & 39 \\
\hline
\end{tabular}


Table A4a.

Plant establishment, shoot development and yield components at four different seed rates at a uniform, standard rate applications in $\mathbf{F H O O}$

UNIFORM

\begin{tabular}{|c|c|c|c|c|c|c|c|c|c|c|c|}
\hline \multirow[b]{3}{*}{$\begin{array}{c}\text { Seeds } \\
m^{-2}\end{array}$} & \multicolumn{5}{|c|}{ Pre $N$ application } & \multicolumn{6}{|c|}{ Best Farm Practice - Uniform Nitrogen } \\
\hline & \multirow[b]{2}{*}{$\begin{array}{c}\text { Autumn } \\
\text { Plant number } \\
\text { (plants } \mathrm{m}^{-2} \text { ) }\end{array}$} & \multirow{2}{*}{$\frac{G S 26}{\underset{2}{\text { Shoots } m^{-}}}$} & \multicolumn{3}{|c|}{$G S 29$} & \multicolumn{2}{|r|}{ GS30 } & \multicolumn{2}{|c|}{ GS35 } & \multicolumn{2}{|r|}{ GS61 } \\
\hline & & & $\begin{array}{c}\text { Shoots } \\
m^{-2}\end{array}$ & GAI & $\begin{array}{c}\text { Green area } \\
\text { per shoot } \\
\left(\mathrm{cm}^{2}\right)\end{array}$ & GAI & $\begin{array}{c}\text { Green area } \\
\text { per shoot } \\
\left(\mathrm{cm}^{2}\right)\end{array}$ & GAI & $\begin{array}{c}\text { Green area } \\
\text { per shoot } \\
\left(\mathrm{cm}^{2}\right)\end{array}$ & GAI & $\begin{array}{c}\text { Green area } \\
\text { per shoot } \\
\left(\mathrm{cm}^{2}\right)\end{array}$ \\
\hline 150 & 120 & 473 & 558 & 0.7 & 10.6 & 1.3 & 20.0 & 4.1 & 92 & 5.5 & 143 \\
\hline 250 & 195 & 547 & 693 & 0.7 & 8.9 & 1.1 & 15.5 & 4.4 & 92 & 7.0 & 147 \\
\hline 350 & 240 & 1161 & 1093 & 1.6 & 13.4 & 1.3 & 17.6 & 7.0 & 111 & 6.3 & 129 \\
\hline 450 & 320 & 1398 & 1607 & 1.6 & 10 & 1.8 & 14.5 & 8.7 & 111 & 8.8 & 140 \\
\hline
\end{tabular}


Table A4b.

Plant establishment, shoot development and yield components at four different seed rates under variable rate $\mathrm{N}$ applications in $\mathrm{FH00}$

VARIABLE

\begin{tabular}{|c|c|c|c|c|c|c|c|c|c|c|c|}
\hline \multirow[b]{3}{*}{$\begin{array}{c}\text { Seeds } \\
m^{-2}\end{array}$} & \multicolumn{5}{|c|}{ Pre $N$ application } & \multicolumn{6}{|c|}{ Precision Farming - Variable Nitrogen } \\
\hline & \multirow[b]{2}{*}{$\begin{array}{c}\text { Autumn } \\
\text { Plant number } \\
\text { (plants } \mathrm{m}^{-2} \text { ) }\end{array}$} & \multirow{2}{*}{$\frac{G S 26}{\underset{2}{\text { Shoots } m^{-}}}$} & \multicolumn{3}{|c|}{$G S 29$} & \multicolumn{2}{|r|}{ GS30 } & \multicolumn{2}{|c|}{ GS35 } & \multicolumn{2}{|r|}{ GS61 } \\
\hline & & & $\begin{array}{c}\text { Shoots } \\
m^{-2}\end{array}$ & GAI & $\begin{array}{c}\text { Green area } \\
\text { per shoot } \\
\left(\mathrm{cm}^{2}\right)\end{array}$ & GAI & $\begin{array}{c}\text { Green area } \\
\text { per shoot } \\
\left(\mathrm{cm}^{2}\right)\end{array}$ & GAI & $\begin{array}{c}\text { Green area } \\
\text { per shoot } \\
\left(\mathrm{cm}^{2}\right)\end{array}$ & GAI & $\begin{array}{c}\text { Green area } \\
\text { per shoot } \\
\left(\mathrm{cm}^{2}\right)\end{array}$ \\
\hline 150 & 120 & 473 & 558 & 0.7 & 10.6 & 1.5 & 18.9 & 4.6 & 105 & 5.8 & 147 \\
\hline 250 & 195 & 547 & 693 & 0.7 & 8.9 & 1.4 & 18.0 & 4.8 & 97 & 6.9 & 142 \\
\hline 350 & 240 & 1161 & 1093 & 1.6 & 13.4 & 1.8 & 17.6 & 4.2 & 81 & 6.9 & 126 \\
\hline 450 & 320 & 1398 & 1607 & 1.6 & 10 & 1.6 & 15.4 & 6.1 & 92 & 7.5 & 130 \\
\hline
\end{tabular}


Table A5a.

Final yields and related economics in four different seed rates under uniform, standard rate $\mathrm{N}$ applications in $\mathrm{FHO0}$

\begin{tabular}{|c|c|c|c|c|c|c|c|c|c|c|}
\hline \multicolumn{5}{|c|}{ Hand Harvest } & \multicolumn{6}{|c|}{ Standard N Economics } \\
\hline $\begin{array}{l}\text { Seeds } \\
m^{-2}\end{array}$ & $\begin{array}{c}\text { Ears } \\
m^{-2}\end{array}$ & $\begin{array}{l}\text { Grains } \\
\text { per ear }\end{array}$ & $\begin{array}{c}T G W \\
(g)\end{array}$ & $\begin{array}{c}H H \\
\text { yield }(t \\
\left.h a^{-1}\right)\end{array}$ & $\begin{array}{l}\text { Seed } \\
\text { costs } \\
\left(\begin{array}{c}\text { h ha } \\
1 \\
{ }^{-}\end{array}\right)\end{array}$ & $\begin{array}{c}\text { Application } \\
\text { cost }\end{array}$ & $\begin{array}{l}N \text { costs } \\
\left(£ h a^{-1}\right)\end{array}$ & $\begin{array}{c}\text { CH } \\
\text { Yield } \\
\left(\text { tha }^{-1}\right)\end{array}$ & $\begin{array}{c}\text { Gross } \\
\text { Margin } \\
\mathrm{CH}(£ \\
\left.h a^{-1}\right)\end{array}$ & $\begin{array}{l}\text { Relative } G M \\
(350 S) C H \\
\quad\left(£ h a^{-1}\right)\end{array}$ \\
\hline 150 & 113 & 55 & 38.6 & 9.7 & 18 & 21 & 60 & 7.9 & 417 & 12 \\
\hline 250 & 126 & 50 & 37.5 & 9.5 & 31 & 21 & 60 & 7.8 & 398 & -6 \\
\hline $350-$ & 130 & 47 & 36.9 & 9.0 & 42 & 21 & 60 & 8.1 & 404 & 0 \\
\hline 450 & 182 & 38 & 37.7 & 10.4 & 53 & 21 & 60 & 7.9 & 381 & -23 \\
\hline
\end{tabular}

$\mathrm{CH}=$ combine harvested

$\mathrm{HH}=$ hand harvested 
Table A5b.

Final yields and related economics in four different seed rates under variable rate $\mathrm{N}$ applications in $\mathbf{F H O 0}$

\begin{tabular}{|c|c|c|c|c|c|c|c|c|c|c|}
\hline \multicolumn{5}{|c|}{ Hand Harvest } & \multicolumn{6}{|c|}{ Variable $N$ Economics } \\
\hline $\begin{array}{l}\text { Seeds } \\
m^{-2}\end{array}$ & $\begin{array}{c}\text { Ears } \\
m^{-2}\end{array}$ & $\begin{array}{l}\text { Grains } \\
\text { per ear }\end{array}$ & $\begin{array}{c}T G W \\
(g)\end{array}$ & $\begin{array}{c}H H \\
\text { yield }(t \\
\left.h a^{-1}\right)\end{array}$ & $\begin{array}{l}\text { Seed } \\
\text { costs } \\
\left(\begin{array}{c}£ \\
1\end{array}\right)\end{array}$ & $\begin{array}{c}\text { Application } \\
\text { cost }\end{array}$ & $\begin{array}{l}N \text { costs } \\
\left(£ h a^{-1}\right)\end{array}$ & $\begin{array}{c}\text { CH } \\
\text { Yield } \\
\left(\text { tha }{ }^{-1}\right)\end{array}$ & $\begin{array}{c}\text { Gross } \\
\text { Margin } \\
C H(£ \\
\left.h a^{-1}\right)\end{array}$ & $\begin{array}{c}\text { Relative } G M \\
(350 S) C H \\
\left(£ h a^{-1}\right)\end{array}$ \\
\hline 150 & 126 & 51 & 39.6 & 10.2 & 18 & 21 & 59 & 8.2 & 437 & 33 \\
\hline 250 & 125 & 49 & 38.4 & 9.3 & 31 & 21 & 57 & 7.8 & 397 & -7 \\
\hline $350-$ & 142 & 42 & 38.7 & 9.3 & 42 & 18 & 40 & 7.8 & 406 & 2 \\
\hline 450 & 145 & 40 & 36.6 & 8.4 & 53 & 18 & 43 & 7.8 & 391 & -13 \\
\hline
\end{tabular}

$\mathrm{CH}=$ combine harvested

$\mathrm{HH}=$ hand harvested 


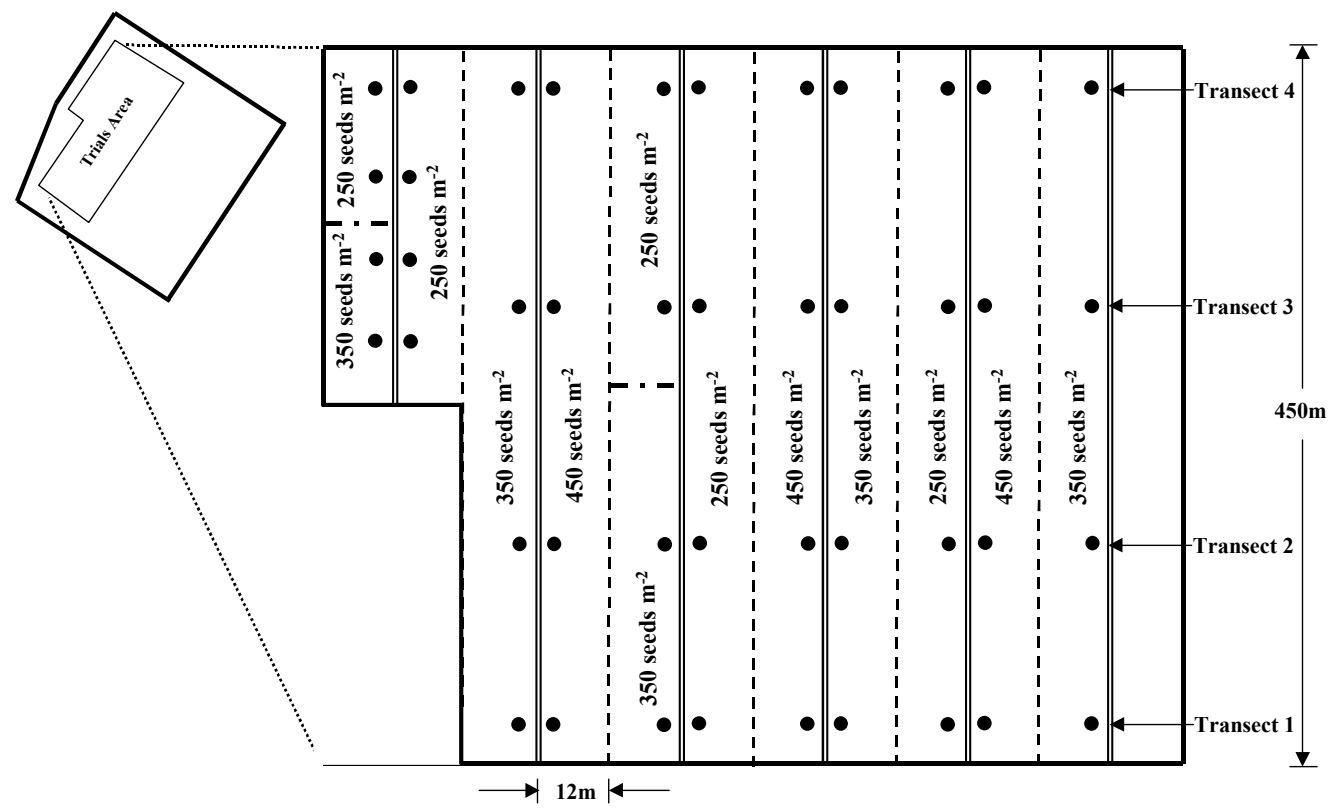

Fig. 1. Field layout of the seed rate experiment in Onion Field, 1998 (ON98). Sampling point; $=$,Tramline, 


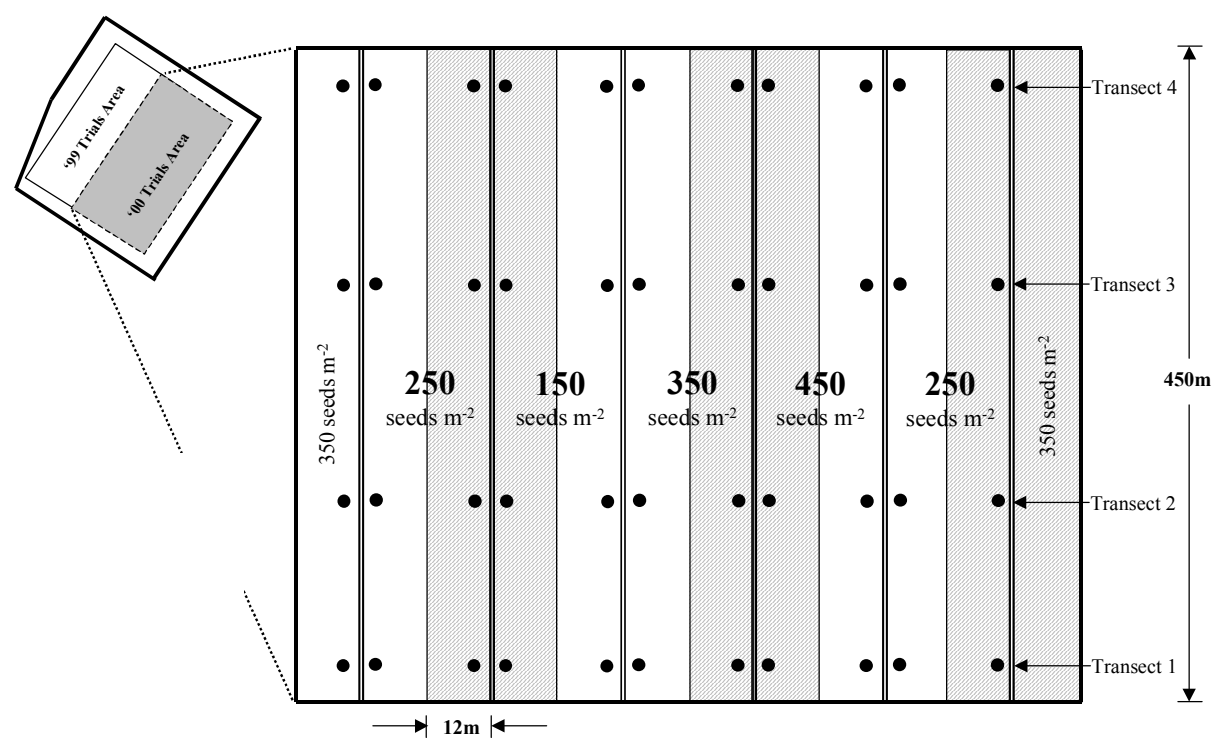

Fig. 2. Field layout of the seed rate and variable nitrogen experiment in Onion Field, 1999 and 2000 (ON99 and ON00: •, Sampling point; $=$,Tramline, $\square$, Standard rate $N ; \square$, Variable rate $N$ 


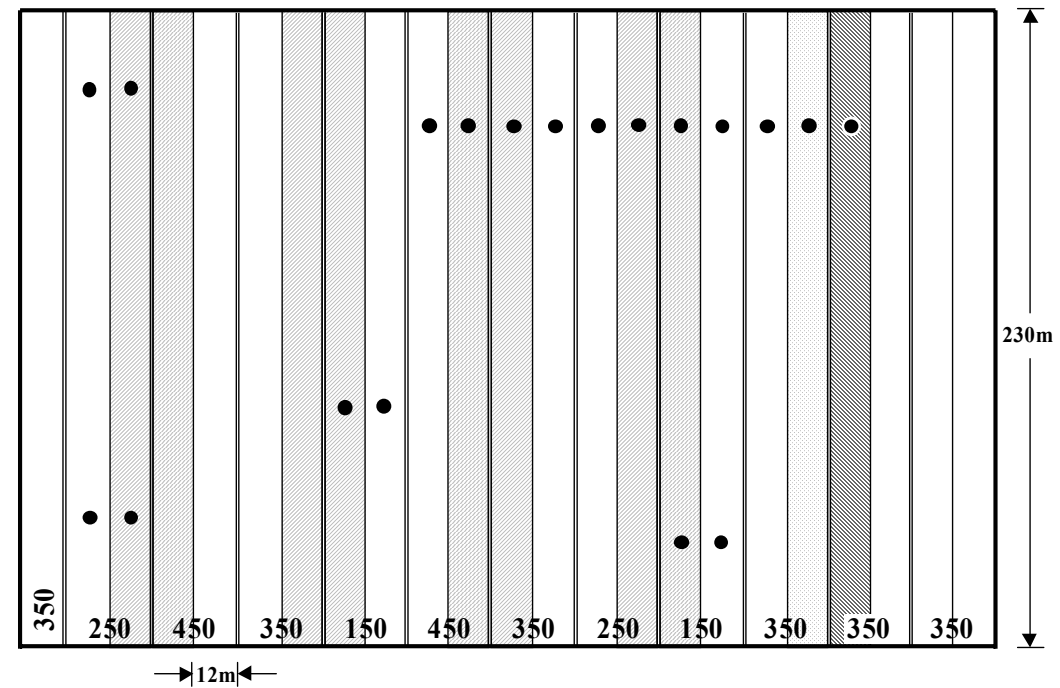

Fig. 3. Field layout of the seed rate and variable nitrogen experiment in Far Highlands, 2000 (FH00): •, Sampling point; $=$,Tramline, $\square$, Standard rate N;

$\square$, Variable rate $N ; \because$, Zero rate $N$; $\mathbf{N}$, Standard $+30 \% N$ 


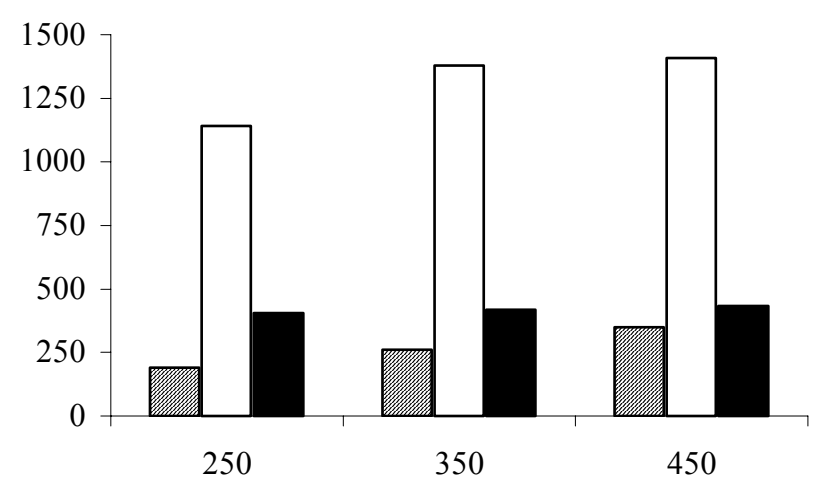

Fig. 4. Plant counts, maximum shoot density and final ear population for three seed rates used in 'Onion Field' in 1998 growing winter wheat, cv. Riband (Triticum

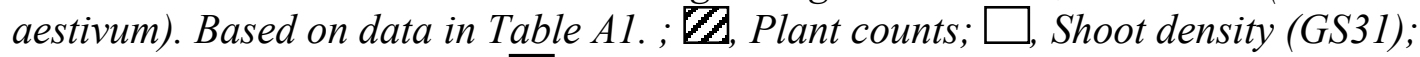




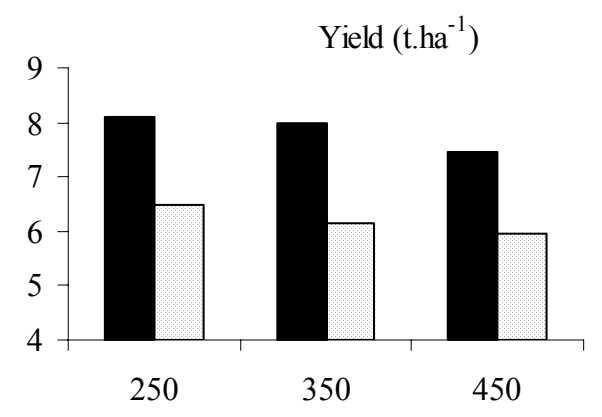

Ear Density $\left(\mathrm{m}^{2}\right)$
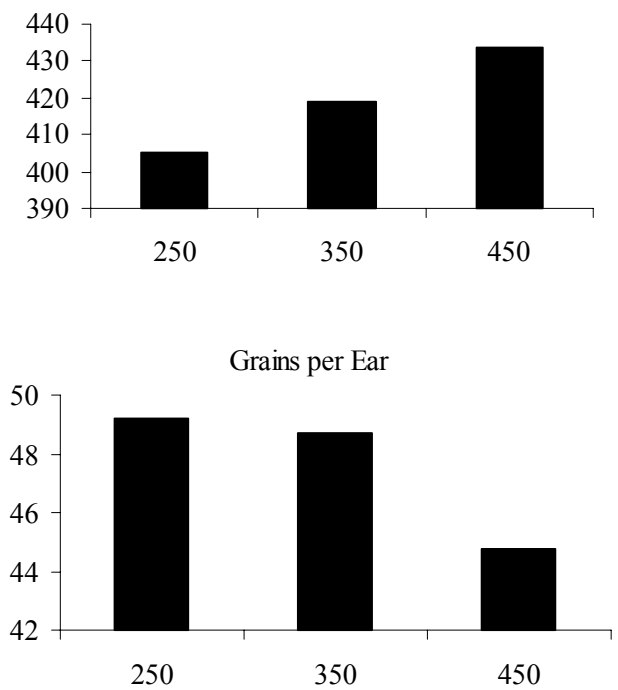

TGW (g)

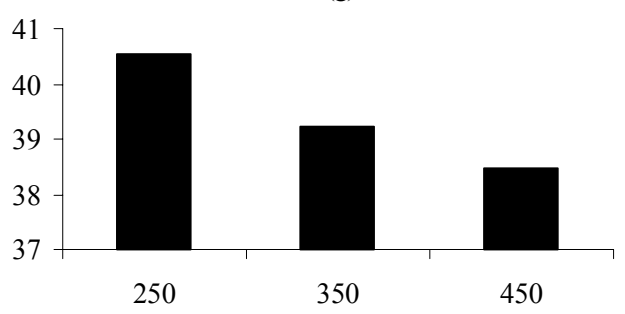

Fig. 5. Final yield (t.ha $a^{-1}$ from two sources and individual yield components derived from the hand harvested samples. Based on data from Table 6. ; 1 , Combine harvest; $\mathbf{\square}$, Hand harvest 


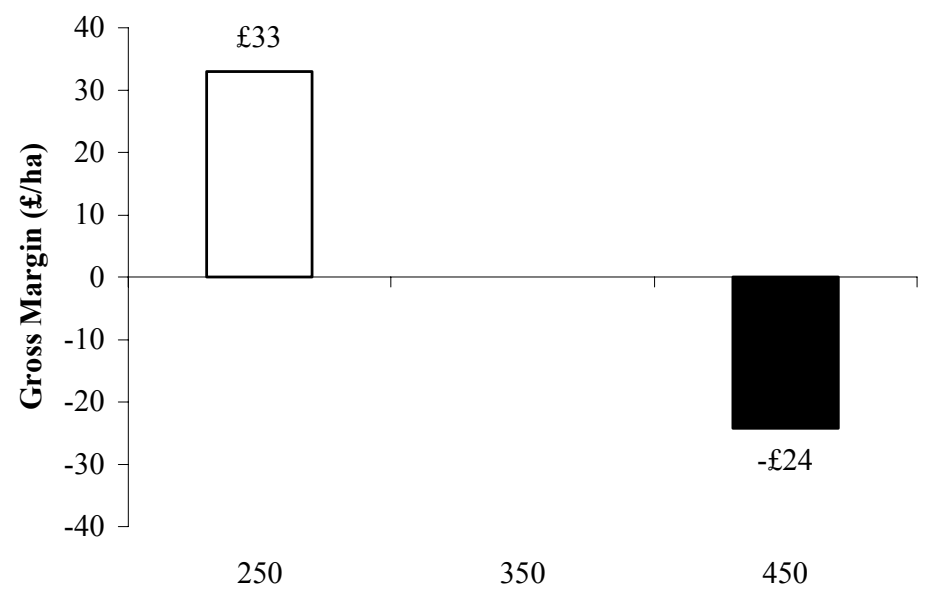

Fig. 6. Relative gross margin benefit accounting for differences seed cost and final yield return compared to the field standard of 350 seeds.m ${ }^{-2}$, which returned 6.2 t.ha ${ }^{-1}$. 


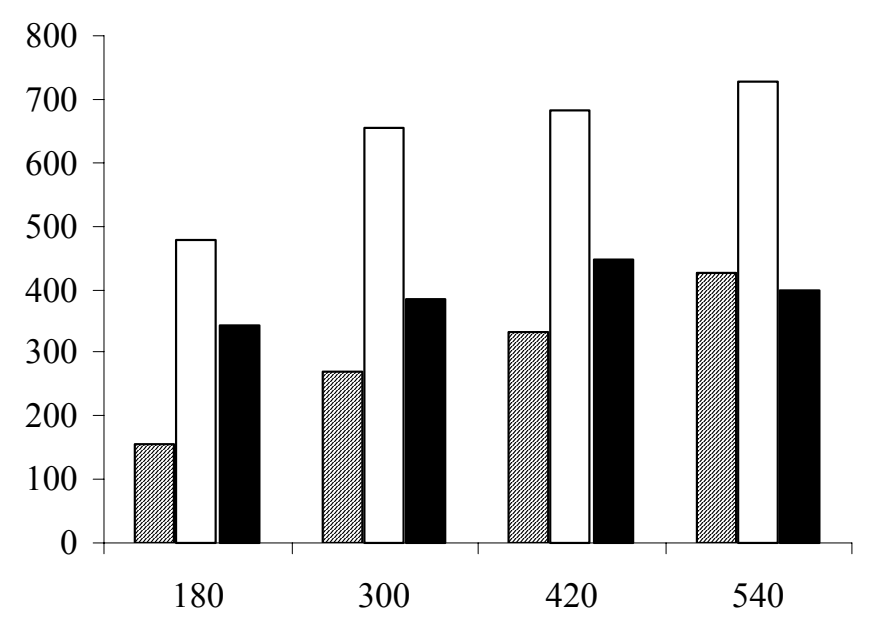

Fig. 7. Plant counts, maximum shoot density and final ear population averages for three seed rates used in 'Onion Field' 1999 growing winter wheat, cv. Abbot (Triticum aestivum), based on data in Table A2: $\square$, Plant Counts; $\square$, Shoot density (GS31); Winal ear population 

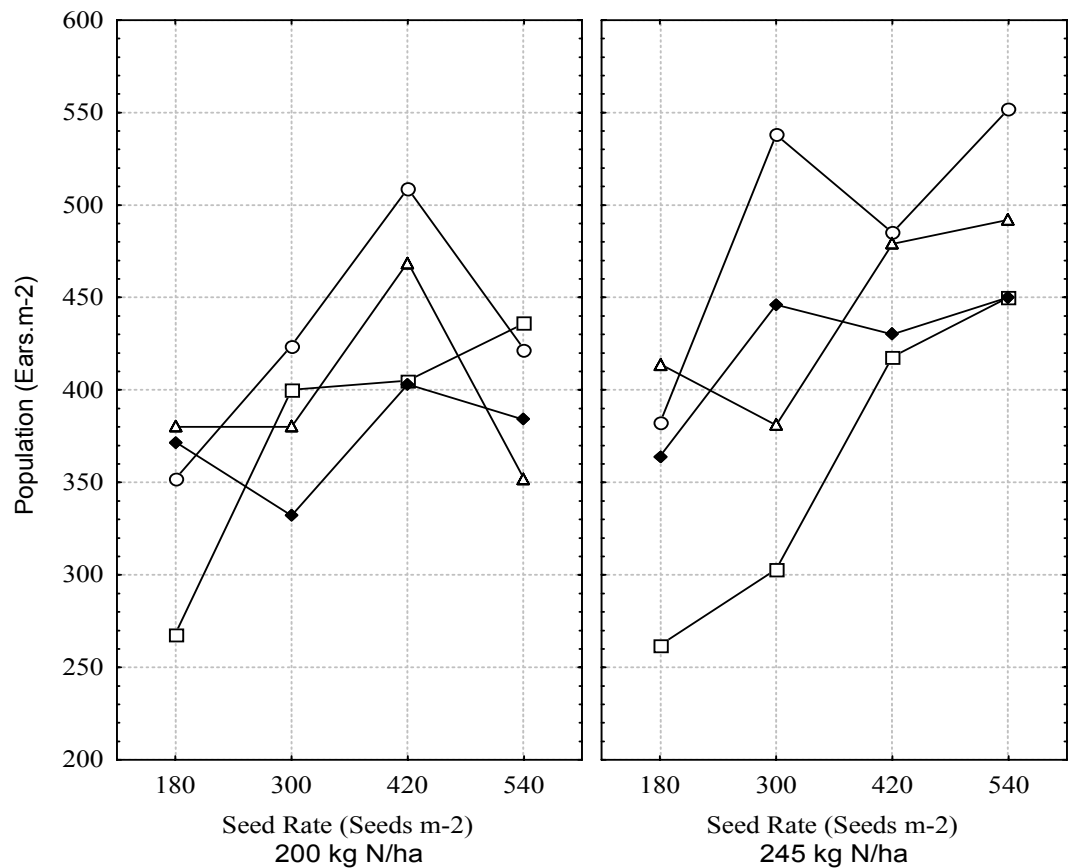

Fig. $8 a-$ The effect of seed rate on the ear population (ears. $m^{-2}$ ) by Transect in ON99: -O-,Transect 1; $\square-$, Transect 2; - , Transect 3; $-\bullet$, Transect 4 

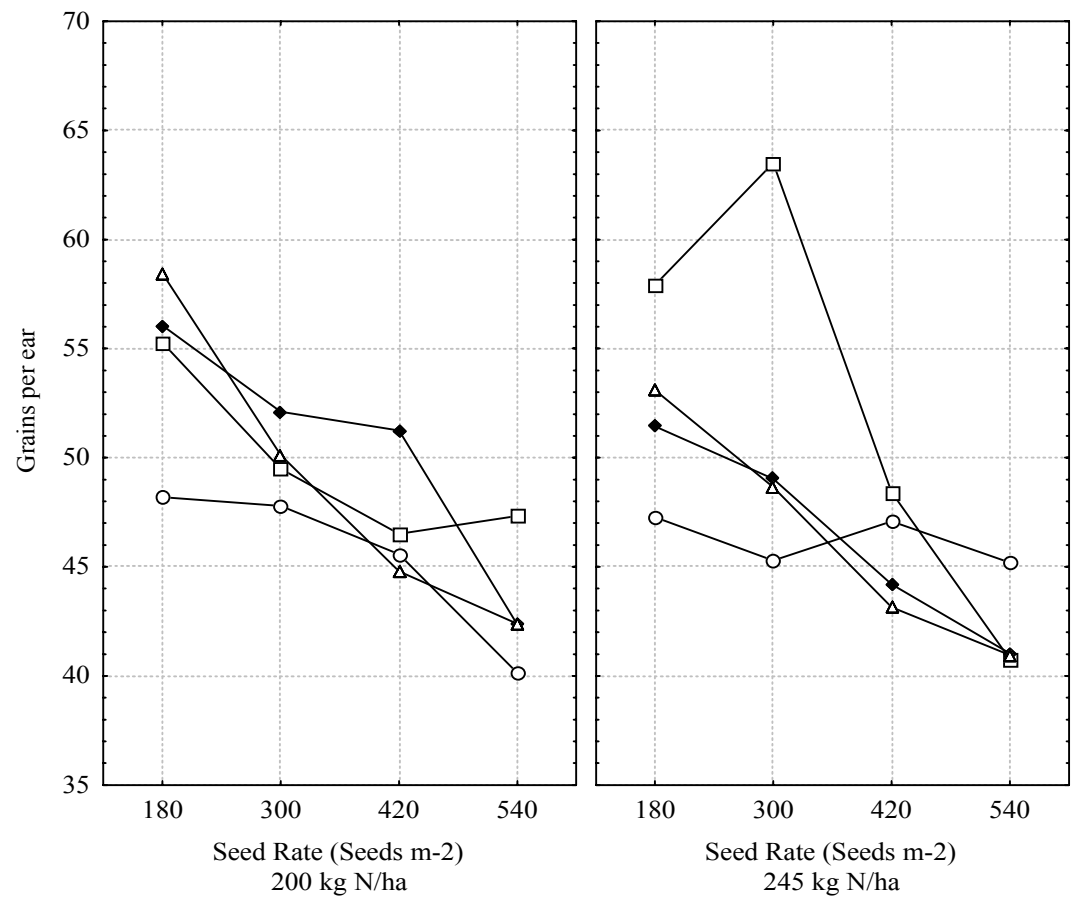

Fig. $8 b$ - The effect of seed rate on the number of grains-per-ear, by Transect in ON99: -O-,Transect $1 ;-\square-$, Transect $2 ;-$, Transect $3 ;-\triangle$, Transect 4 

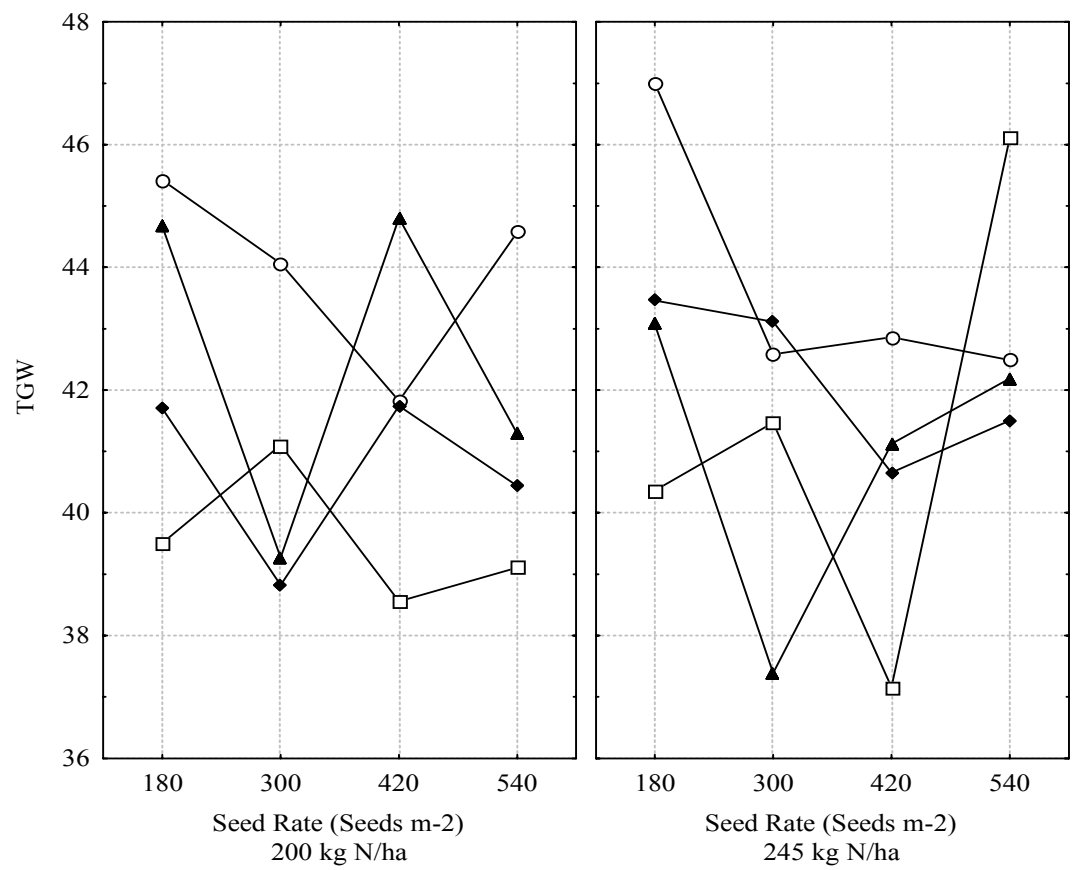

Fig. $8 c$ - The effect of seed rate on the TGW (g), by Transect in ON99: - - -,Transect 1; $\square-$, Transect 2; - , Transect $3 ;-\triangle$, Transect 4 

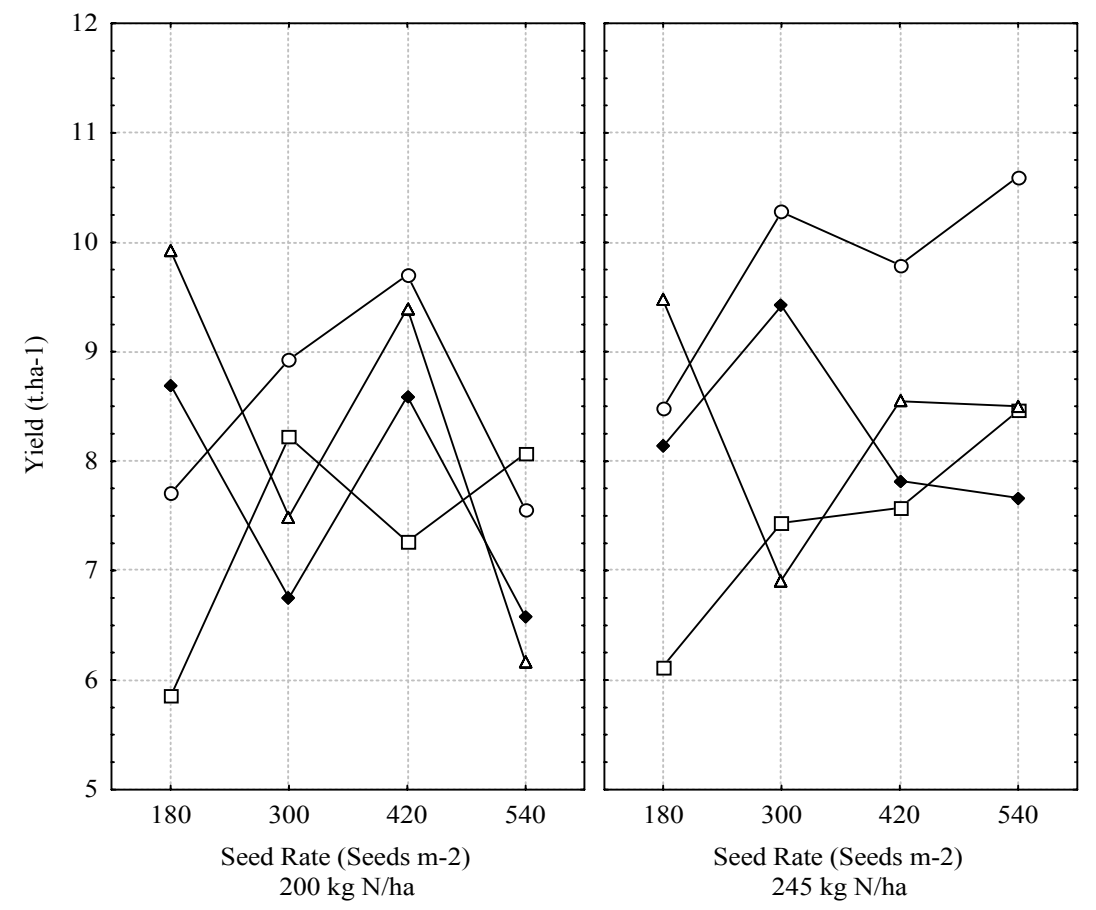

Fig. $8 d$ - The effect of seed rate on hand-measured yield (HH), by Transect in ON99: $-\bigcirc-$,Transect $1 ;-\square-$, Transect $2 ;-\checkmark$, Transect $3 ;-\triangleleft$, Transect 4 


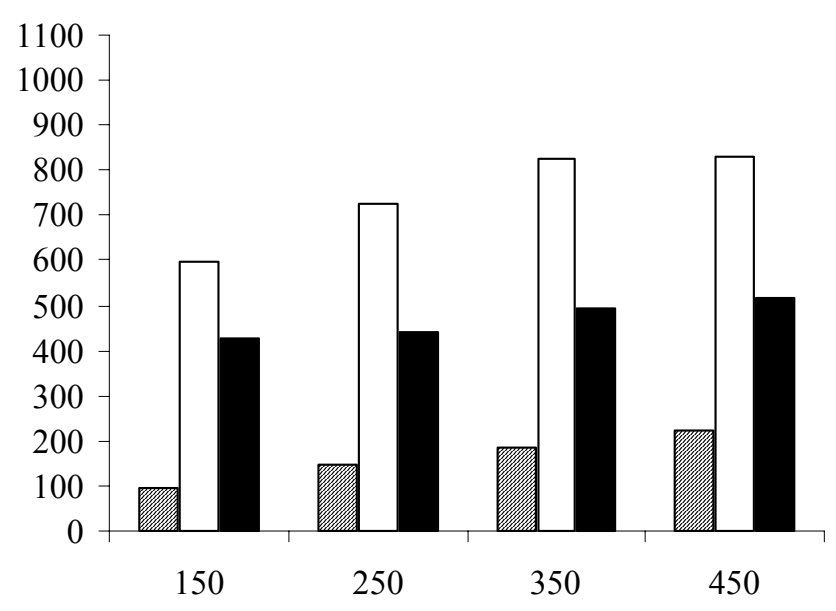

Fig. 9. Plant counts, maximum shoot density and final ear population averages for three seed rates used in 'Onion Field' 2000 growing winter wheat, cv. Malacca (Triticum aestivum): $\square$, Plant Counts; $\square$, Shoot density (GS31); $\square$, Final ear population 

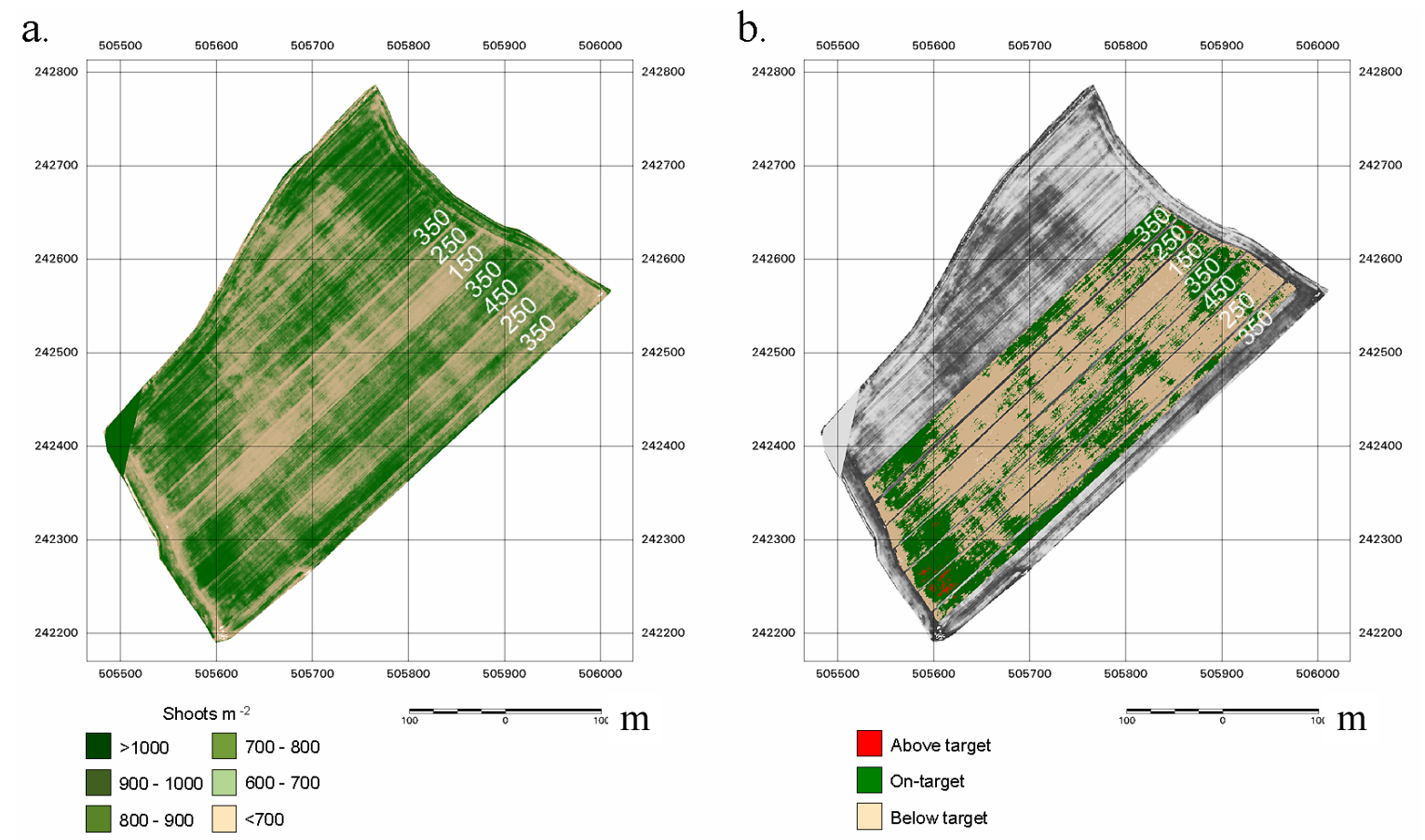

Fig. 10. a. Calibrated shoot map of 'Onion Field' on $5^{\text {th }}$ March, 2000, showing the effects of four different seed rates $\left(150,250,350\right.$ and 450 seeds. $\left.\mathrm{m}^{-2}\right) ; \boldsymbol{b}$. areas classified as above, below and on-target, according to Table 3.

Colour Print and Online 

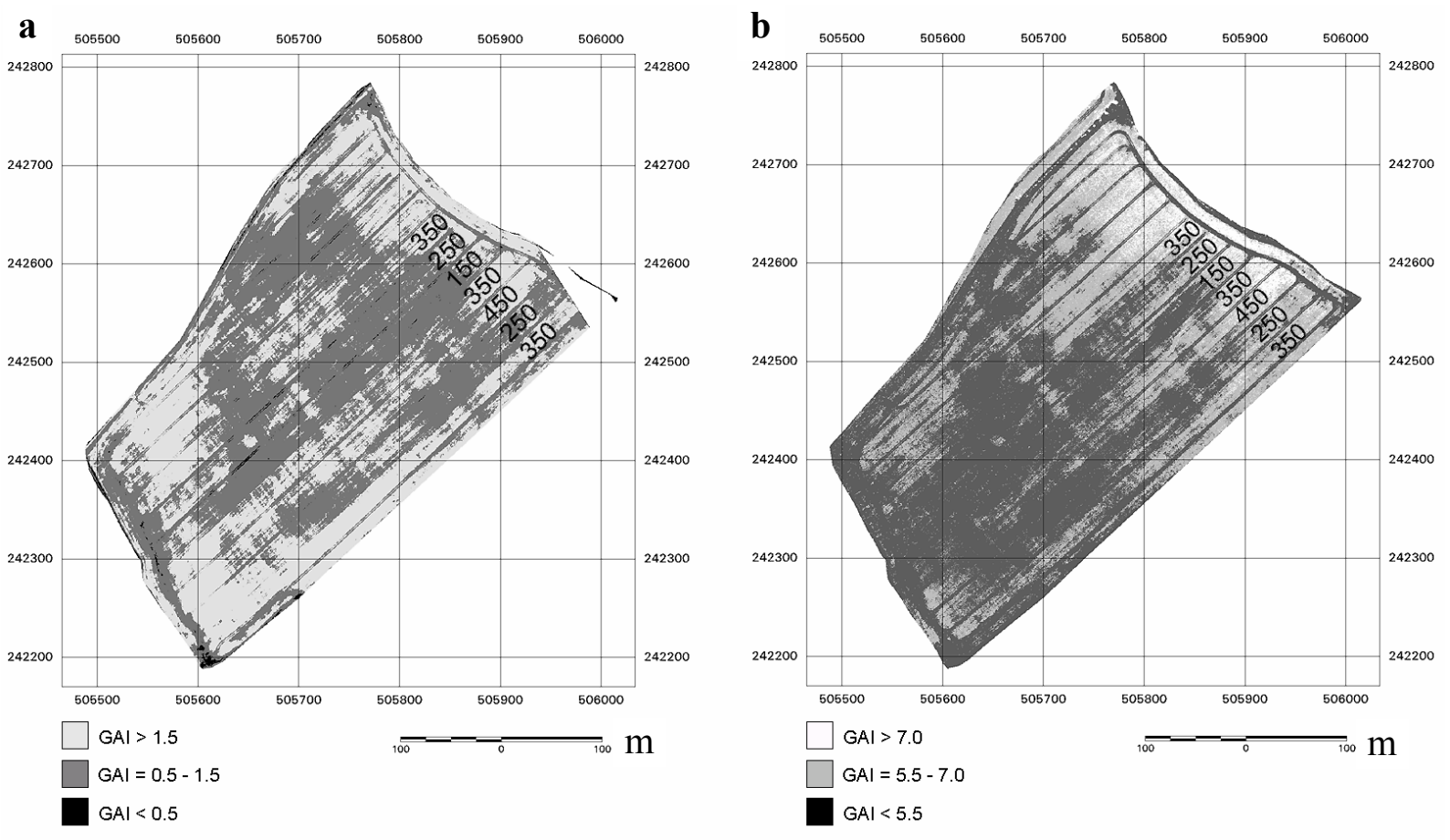

Fig. 11. Calibrated GAI map of 'Onion Field' on a. $29^{\text {th }}$ April, 2000, and b. 24 ${ }^{\text {th }}$ May, 2000. Seed-rate strips labelled accordingly in seeds. $m^{-2}$ 

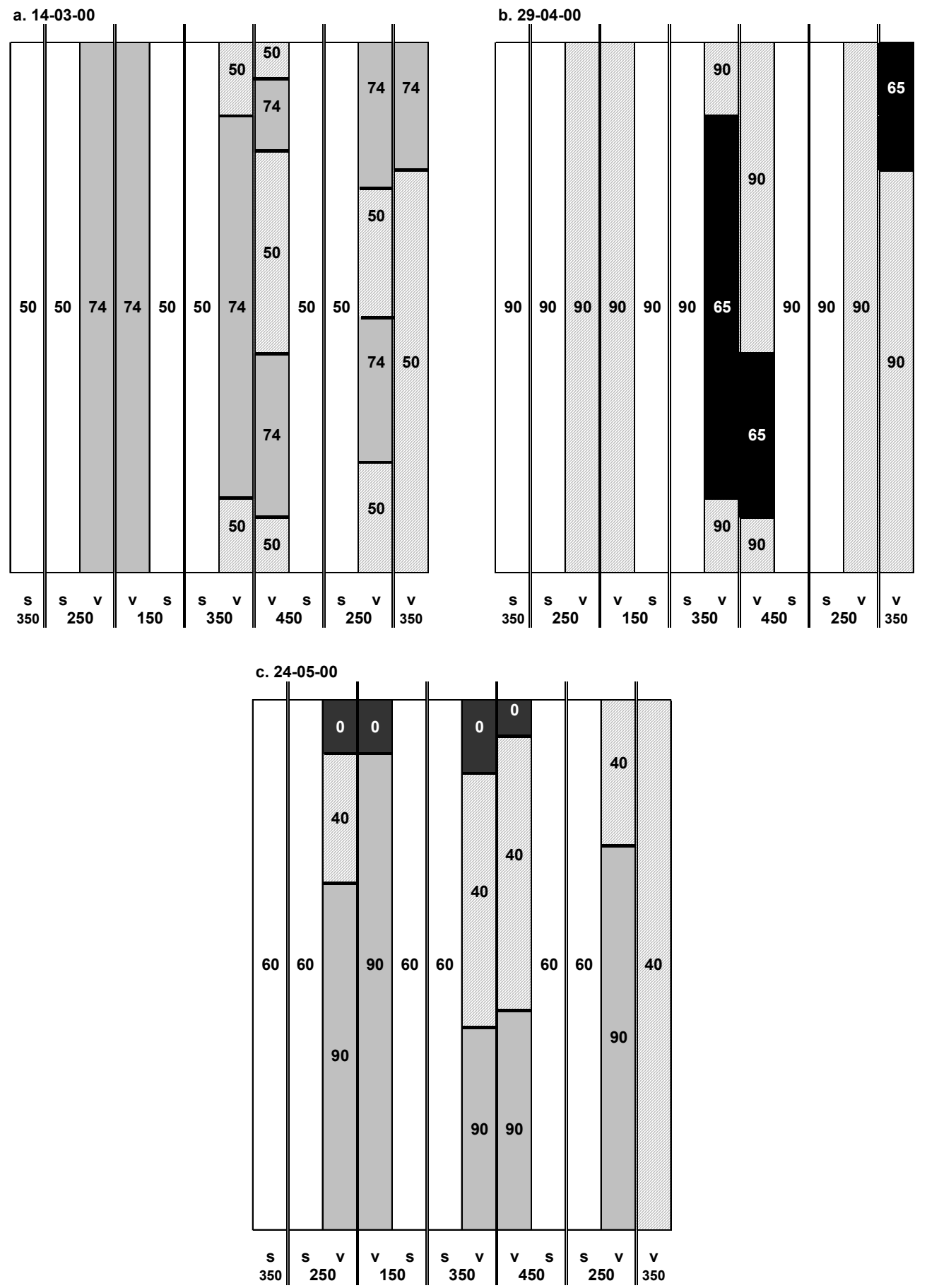

Fig. 12. Nitrogen application layouts and rates for the three application dates in ON00: a. $14^{\text {th }}$ March; b. $29^{\text {th }}$ April; c. $24^{\text {th }}$ May, 2000. 
a.

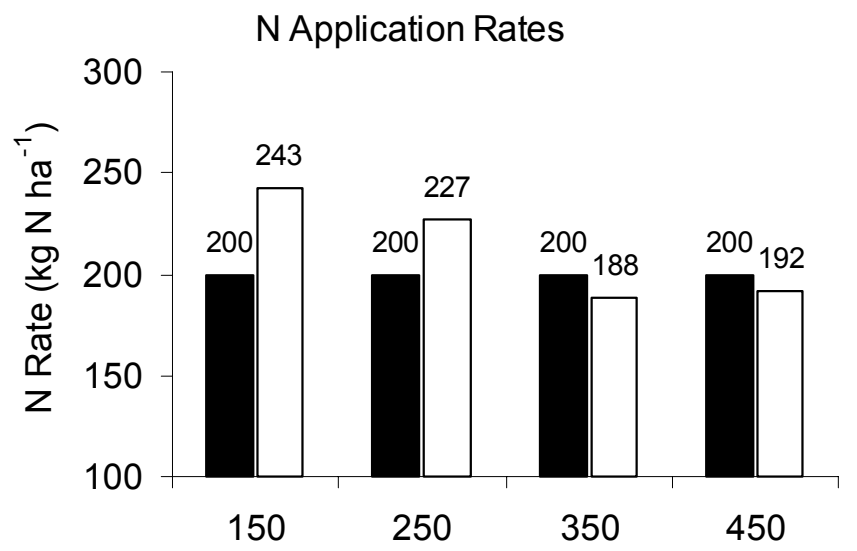

b.

Yield

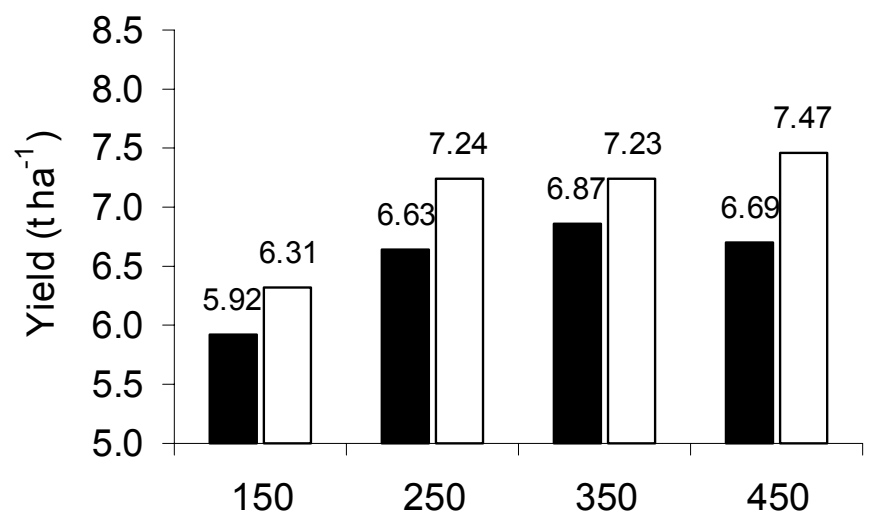

C.

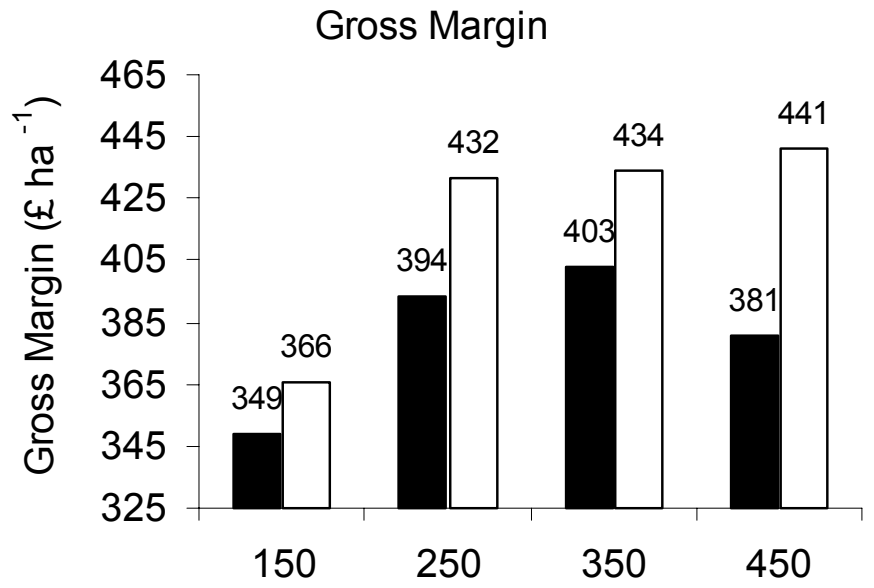

Fig. 13. The result of applying variable vs. standard $N$ application on final yield, total applied $N$ and gross margin in Onion field 2000 (ONO0): 


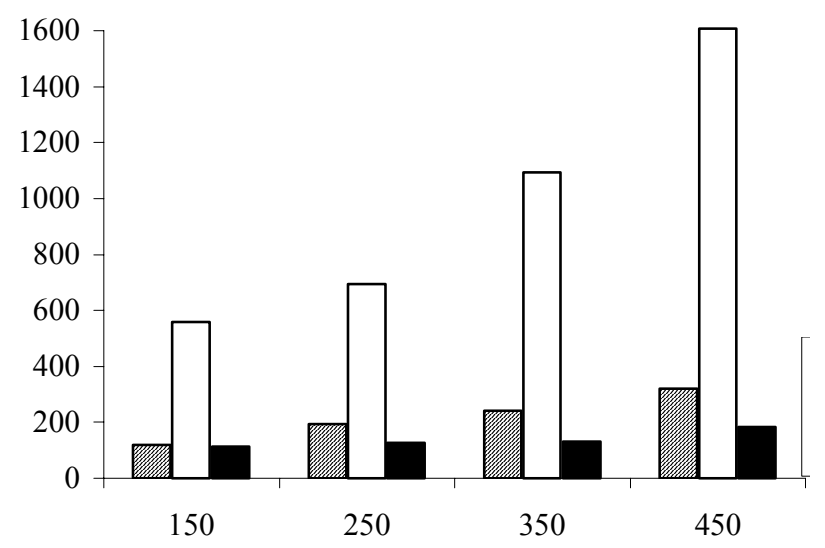

Fig. 14. Plant counts, maximum shoot density and final ear populations for four seed rates (uniform N) used in Far Highlands 2000 growing winter wheat, cv. Consort (Triticum aestivum), based on data in Table A4a: $\square$, Plant Counts; $\square$, Shoot density (GS31); $\mathbf{\square}$, Final ear population 


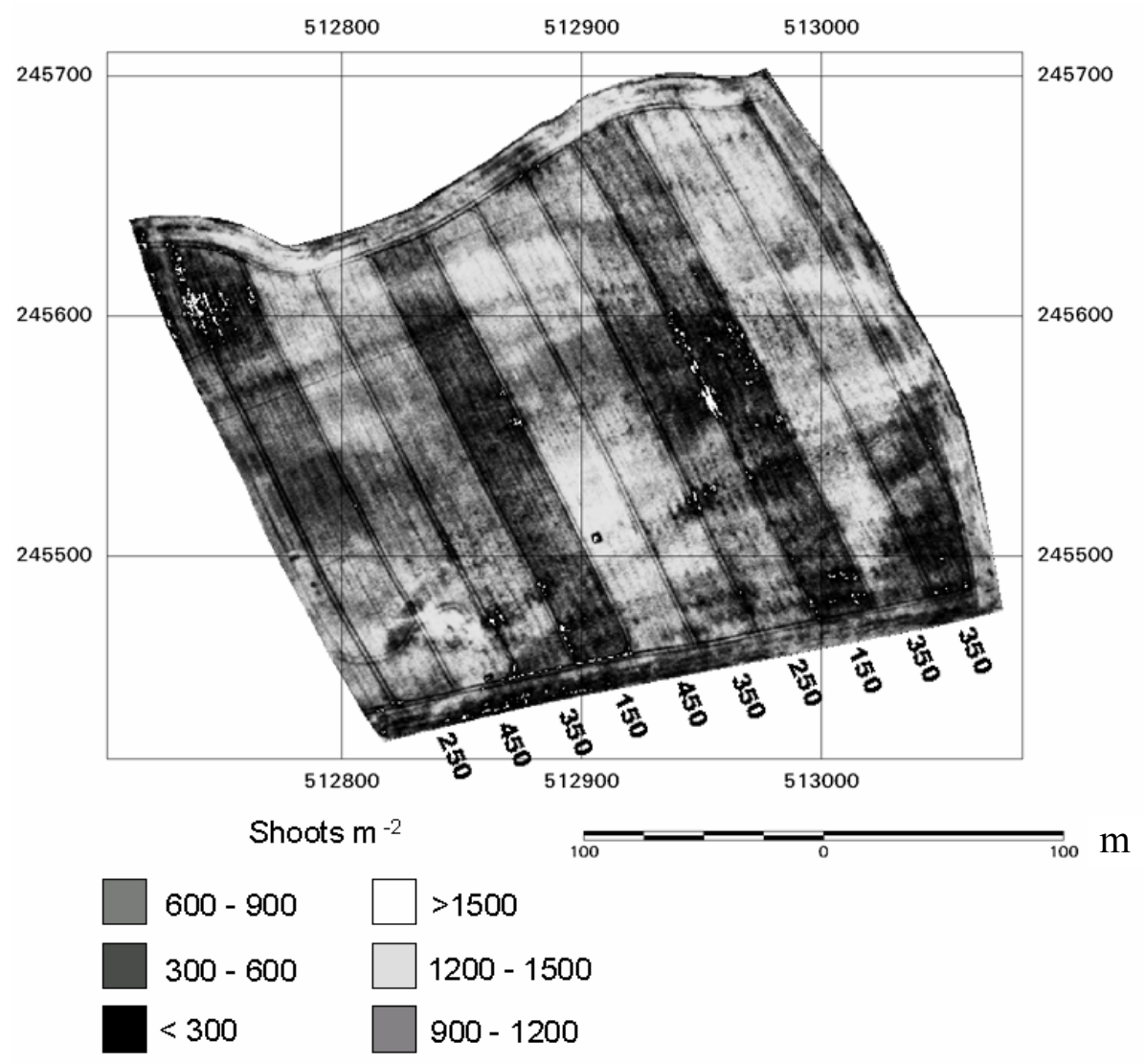

Fig. 15a. Calibrated shoot density map of Far Highlands taken on $5^{\text {th }}$ March, 2000, where the effect of seed rate is very apparent. 
a. $15-03-00$

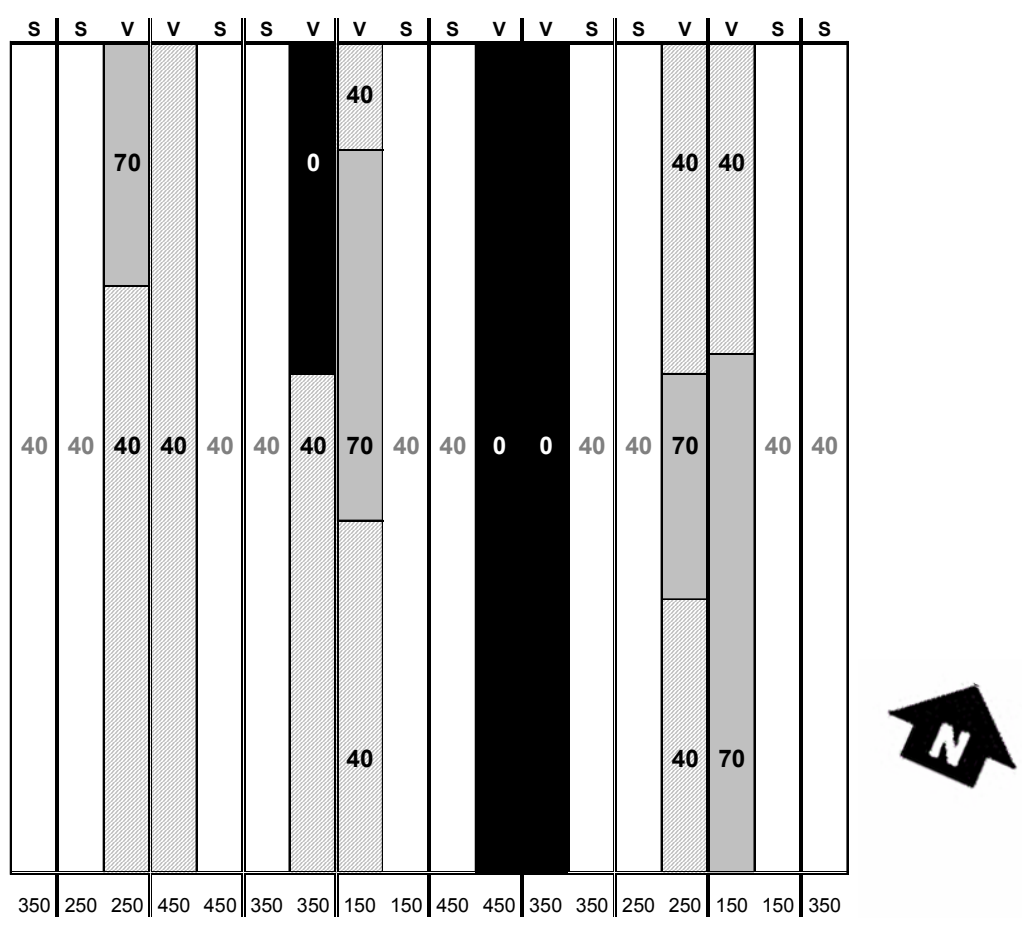

Fig. 15b. Schematic application map of the fertilizer applied at the first timing. 


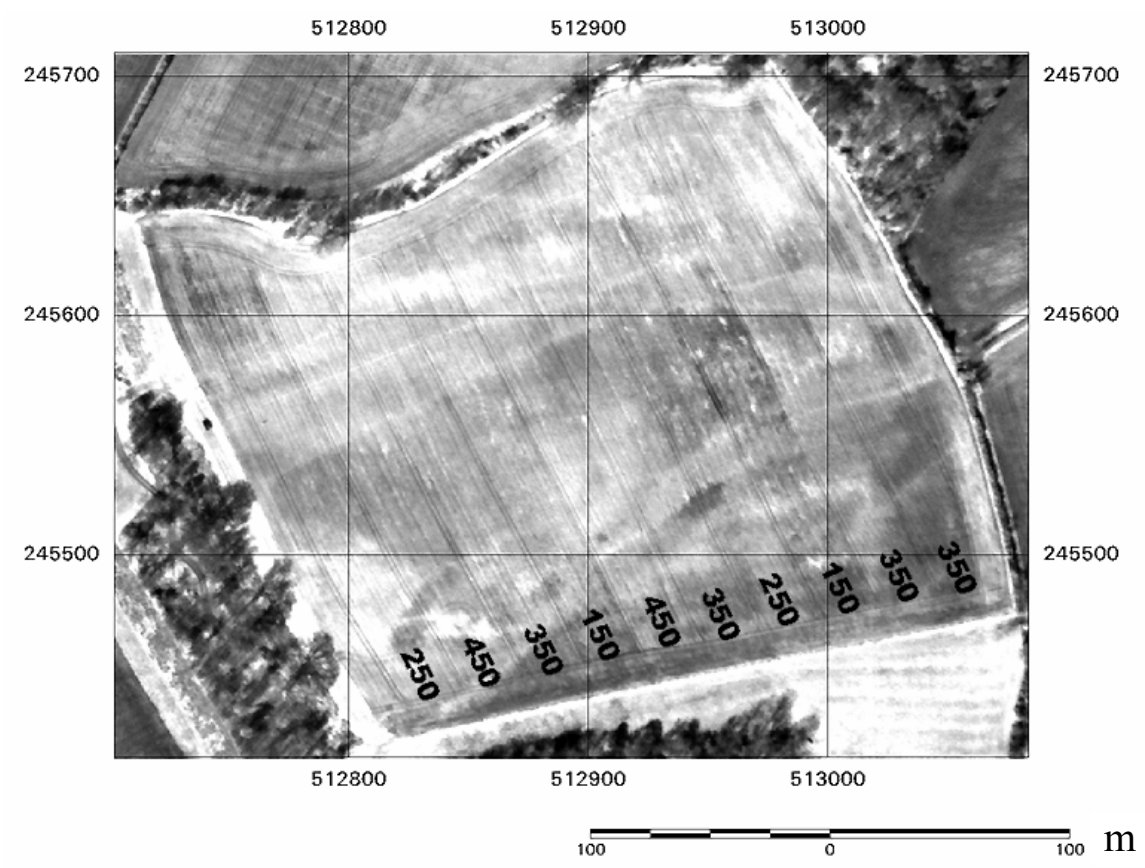

Fig. 16a. Uncalibrated NIR image of Far Highlands taken on $11^{\text {th }}$ April, 2000. The very bright areas represent patches of weeds, although weeds were present in most areas to a lesser degree. 


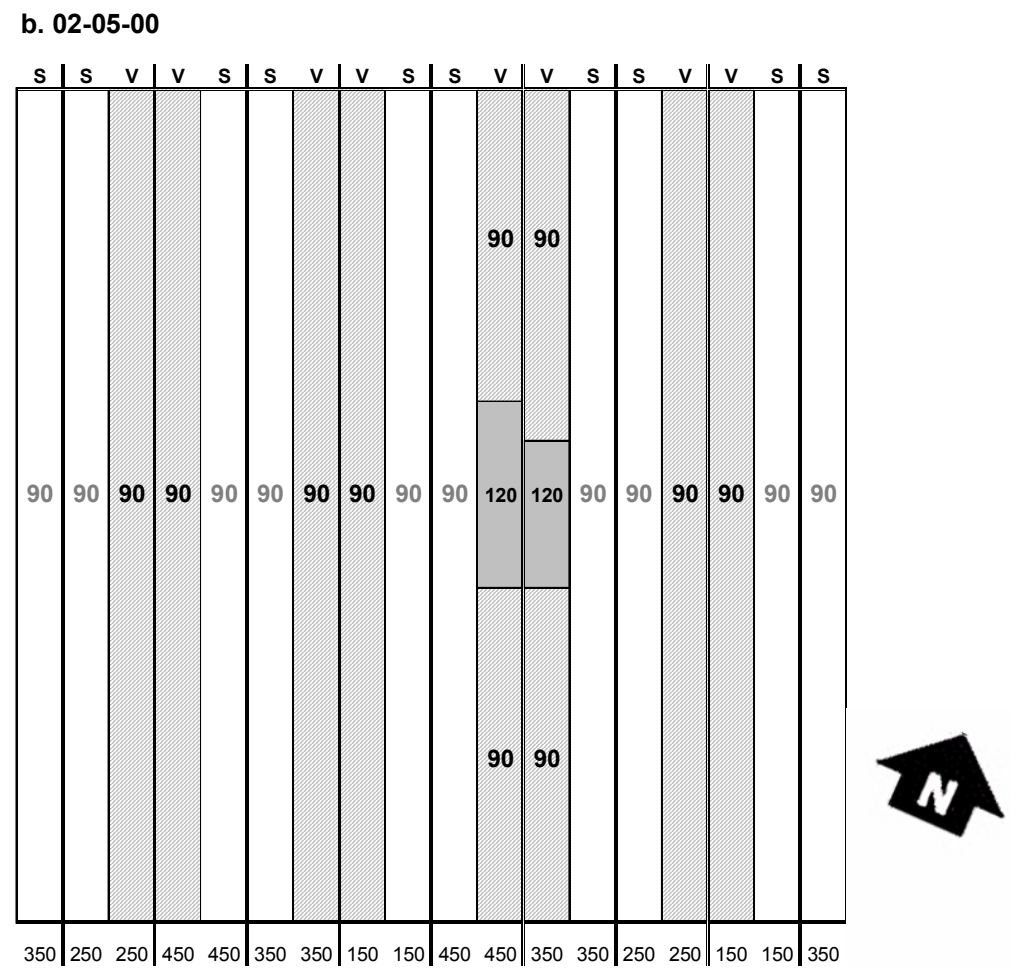

Fig. 16b. Schematic application map of the fertilizer applied on the $2^{\text {nd }}$ May, 2000. The $120 \mathrm{~kg} \mathrm{~N} \mathrm{ha}^{-1}$ dose applied in the 350 and 450 strip correspond to an area of waterlogging. 


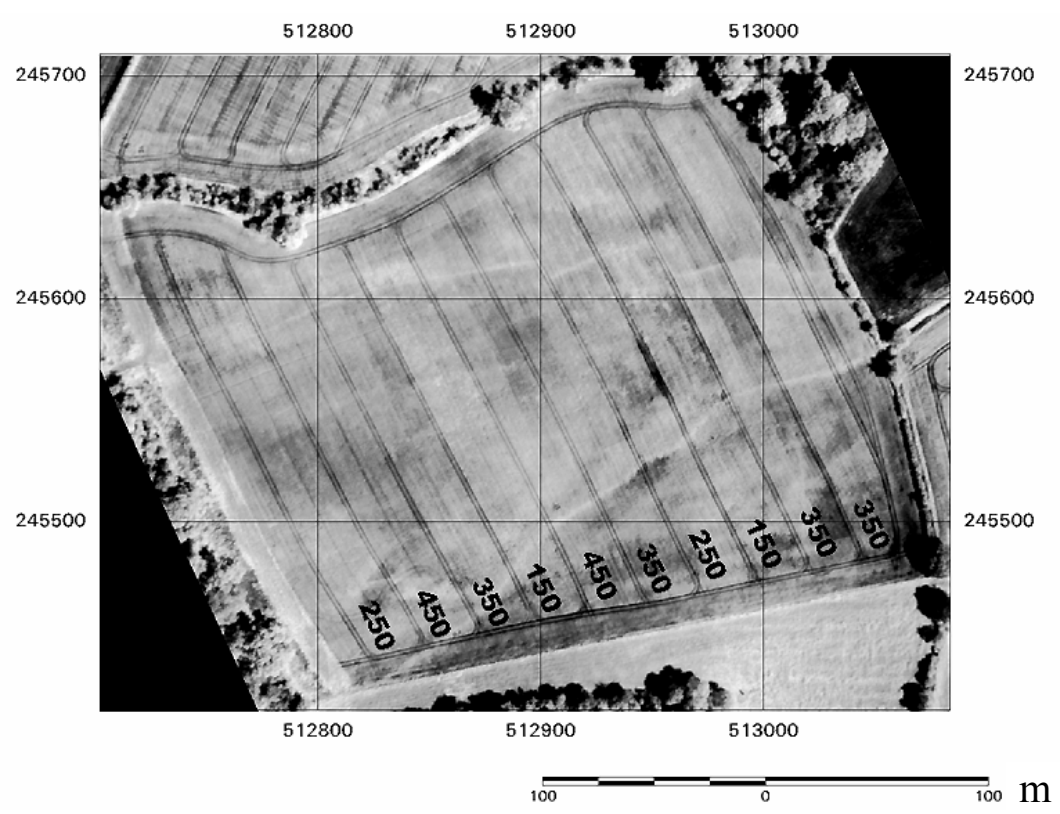

Fig. 17a. Uncalibrated NIR image of Far Highlands taken on $25^{\text {th }}$ May, 2000. The effect of the variable vs. uniform application can be seen particularly well in the higher seed-rate strips. 


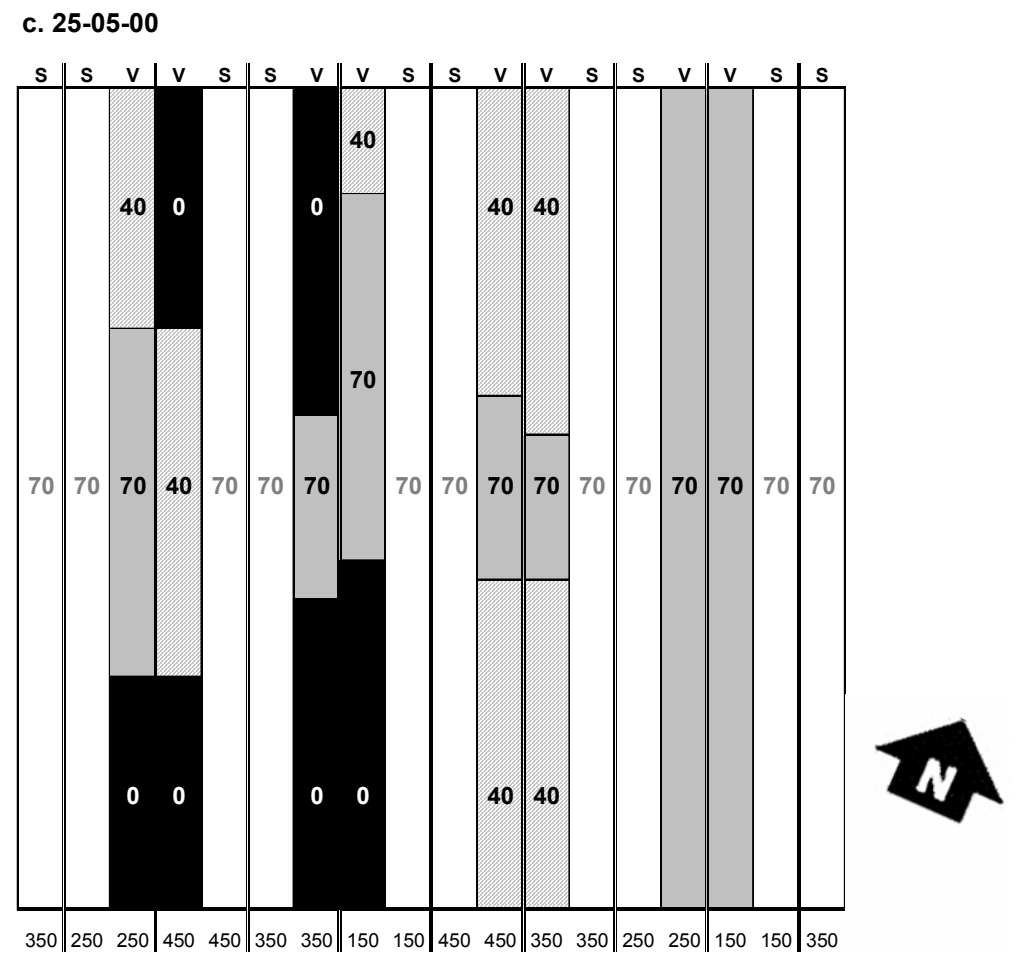

Fig. 17b. Schematic application map of the fertilizer applied at the last $N$ timing. 
a.

N Application Rates

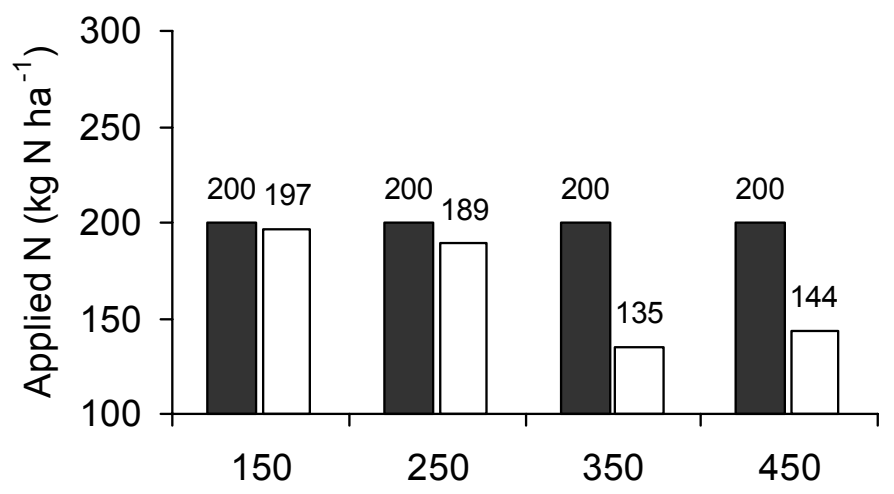

b.

Yield

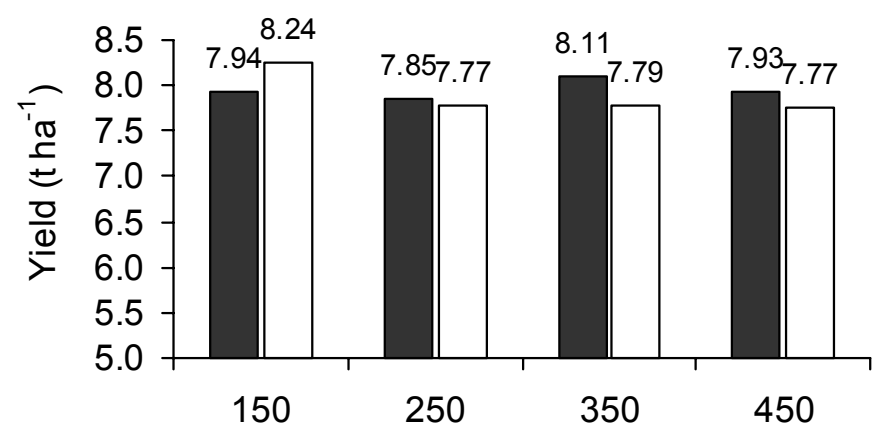

c.

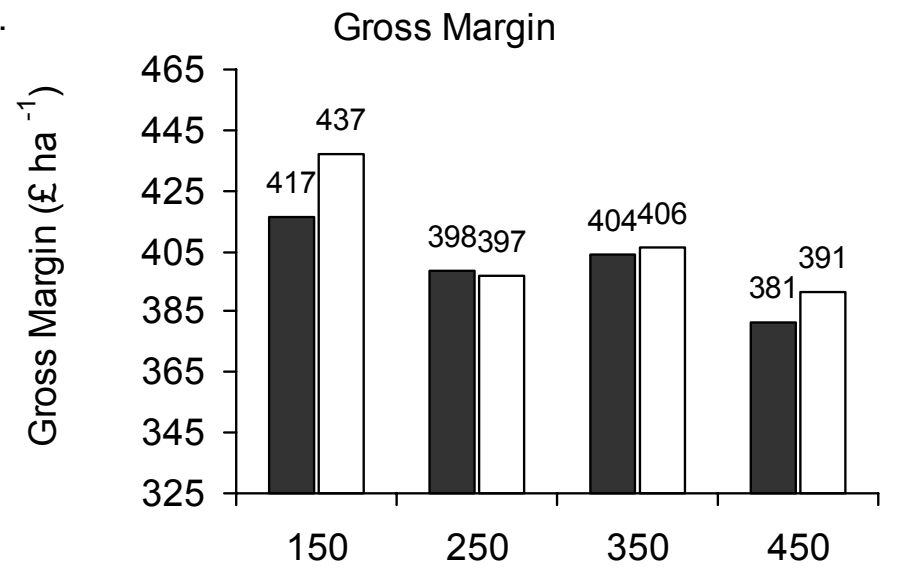

Fig. 18. The result of applying variable vs. standard $N$ application on final yield, total applied $N$ and gross margin in Far Highlands 2000 (FHO0):

$\square$, Variable $N$; $\square$, Standard N 


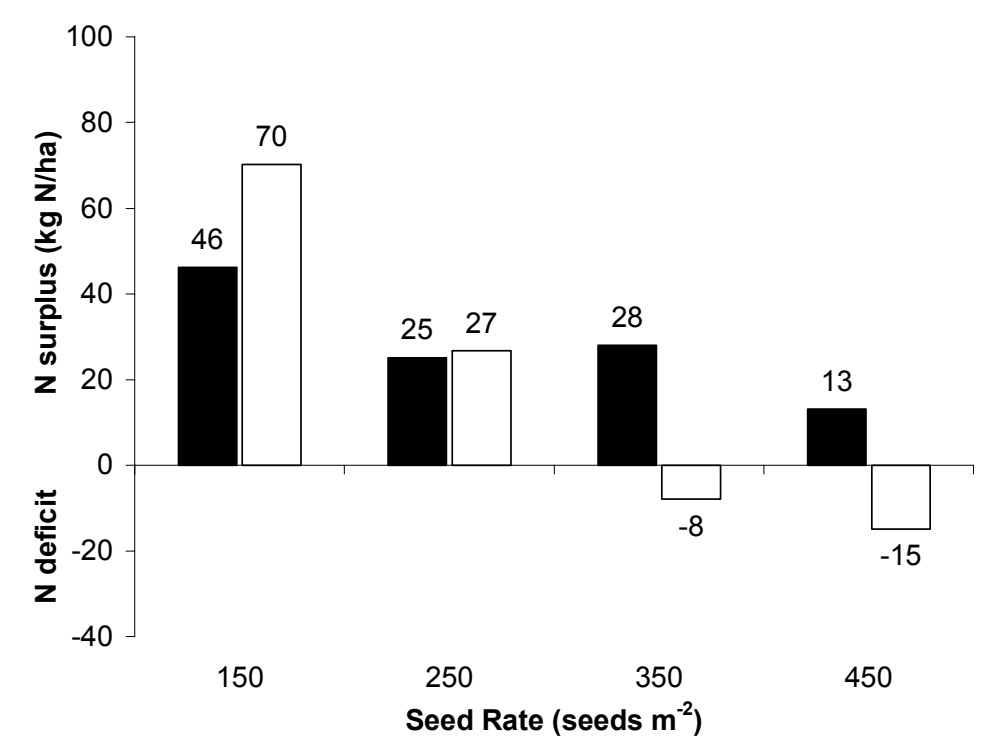

Fig. 19. Surplus or deficit of applied nitrogen relative to off-take in grain and straw at Onion Field in 2000 (ONO0). $\square$, Variable N; $\mathbf{\square}$, Standard N 

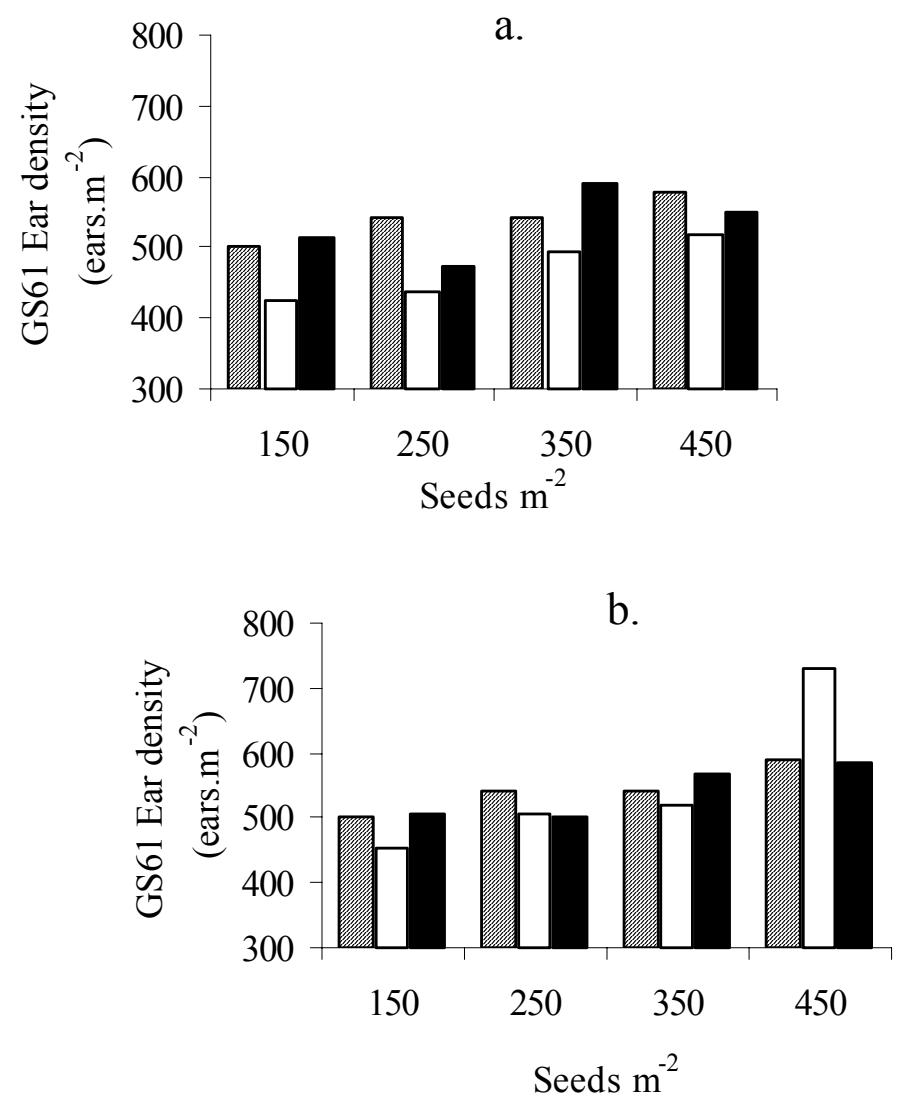

Fig. 20. Seed rate vs. ear density at GS61 for the standard and variable strips compared with desired target density for a. ON00 and b. FH00 : $\square$, Standard; Variable; $\square$, Target 